Article

\title{
Podiform Chromitites and PGE Mineralization in the Ulan-Sar'dag Ophiolite (East Sayan, Russia)
}

\author{
Olga N. Kiseleva ${ }^{1, *}$, Evgeniya V. Airiyants ${ }^{1}$, Dmitriy K. Belyanin ${ }^{1,2} \oplus$ and \\ Sergey M. Zhmodik ${ }^{1,2}$ \\ 1 Sobolev Institute of Geology and Mineralogy, Siberian Branch Russian Academy of Science, pr. Academika \\ Koptyuga 3, Novosibirsk 630090, Russia; jenny@igm.nsc.ru (E.V.A.); bel@igm.nsc.ru (D.K.B.); \\ zhmodik@igm.nsc.ru (S.M.Z.) \\ 2 Faculty of Geology and Geophysics, Novosibirsk State University, Novosibirsk 630090, Russia \\ * Correspondence: kiseleva_on@igm.nsc.ru; Tel.: +7-983-126-70-72
}

Received: 26 December 2019; Accepted: 2 February 2020; Published: 7 February 2020

\begin{abstract}
In this paper, we present the first detailed study on the chromitites and platinum-group element mineralization (PGM) of the Ulan-Sar'dag ophiolite (USO), located in the Central Asian Fold Belt (East Sayan). Three groups of chrome spinels, differing in their chemical features and physical-chemical parameters, under equilibrium conditions of the mantle mineral association, have been distinguished. The temperature and log oxygen fugacity values are, for the chrome spinels I, from 820 to $920{ }^{\circ} \mathrm{C}$ and from (-0.7) to (-1.5); for chrome spinels II, 891 to $1003{ }^{\circ} \mathrm{C}$ and (-1.1) to (-4.4); and for chrome spinels III, 738 to $846^{\circ} \mathrm{C}$ and $(-1.1)$ to $(-4.4)$, respectively. Chrome spinels I were formed through the interaction of peridotites with mid-ocean ridge basalt (MORB)-type melts, and chrome spinels II were formed through the interaction of peridotites with boninite melts. Chrome spinels III were probably formed through the interaction of andesitic melts with rocks of an overlying mantle wedge. Chromitites demonstrate the fractionated form of the distribution of the platinum-group elements (PGE), which indicates a high degree of partial melting at $20-24 \%$ of the mantle source. Two assemblages of PGM have been distinguished: The primary PGE assemblage of Os-Ir-Ru alloys-I, $(\mathrm{Os}, \mathrm{Ru}) \mathrm{S}_{2}$, and IrAsS, and the secondary PGM assemblage of Os-Ir-Ru alloys-II, $\mathrm{Os}^{0}, \mathrm{Ru}^{0}, \mathrm{RuS}_{2}, \mathrm{OsS}_{2}$, IrAsS, RhNiAs with $\mathrm{Ni}, \mathrm{Fe}$, and $\mathrm{Cu}$ sulfides. The formation of the secondary phases of PGE occurred upon exposure to a reduced fluid, with a temperature range of $300-700{ }^{\circ} \mathrm{C}, \log$ sulfur fugacity of $(-20)$, and pressure of $0.5 \mathrm{kbar}$. We have proposed a scheme for the sequence of the formation and transformation of the PGMs at various stages of the evolution of the Ulan-Sar'dag ophiolite.
\end{abstract}

Keywords: ophiolite; chromitites; PGE mineralogy; geodynamic setting

\section{Introduction}

Podiform chromitites are associated with restite peridotites in ophiolite complexes [1-5]. The concentration, platinum-group element distribution, and mineral form and composition of chrome spinels in podiform chromitites are sensitive indicators of mantle processes: the partial melting degree, initial melt sources, and melt saturation with volatile components $\left(\mathrm{S}, \mathrm{H}_{2} \mathrm{O}\right.$, etc.) [6-14]. Thus, the geochemical features of chromitites, their distribution and the mineral composition of PGE can be used to evaluate the physical-chemical parameters, mineral equilibria parameters, initial melt composition and geodynamic setting of ophiolite formations [14-22]. The use of an olivine-chrome spinel and olivine geothermometer, as well as experimental data on the temperature equilibria of the primary PGMs, provides important information on the formation temperatures of the mantle olivine spinel PGM assemblage and deformation processes [23-25]. The chemical composition of chrome spinels and PGMs, the microstructural features of this assemblage, and accessory sulfide mineralization give 
important information for the reconstruction of magmatic, hydrothermal, and metamorphic processes. In this paper, we describe the chemistry of chrome spinels, the geochemical features of chromitites and PGMs from chromitites, the physical-chemical parameters of mineral equilibria, and the alteration of PGE-chromite mineralization in the mantle peridotites of the Ulan-Sar'dag ophiolite.

\section{Materials and Methods}

Twenty-one samples of chromitites from the western part of Ulan-Sar'dag were studied. The chemical composition of chrome spinels and olivines and the $\mathrm{Al}_{2} \mathrm{O}_{3}$ impurities in olivine were determined by wavelength-dispersive analysis using a Camebax-micro electron microprobe from the Sobolev Institute of Geology and Mineralogy, Russian Academy of Science, Novosibirsk, Russia (Analytical Center for multi-elemental and isotope research SB RAS). A JEOL JXA-8100 analysis methodology specific to olivines to obtain their trace elements has been elaborated: The accelerating voltage is $20 \mathrm{kV}$, the probe current is $400 \mathrm{nA}$, and the counting time per line and background measurement are both $10 \mathrm{~s}$. The number of measurements per analysis is 25 [26]. For an error of 10 relative $\%$, the quantitation limit of $\mathrm{Al}_{2} \mathrm{O}_{3}$ is within $45-100 \mathrm{ppm}$. The analytical conditions for olivines and chrome spinels are as follows: The accelerating voltage is $20 \mathrm{kV}$, the probe current is $30 \mathrm{nA}$, the beam size is $2 \mu \mathrm{m}$, and the signal accumulation time is $10 \mathrm{~s}$. The standards used were natural and synthetic silicates and oxides. The detection limit for oxides was $0.01-0.03 \mathrm{wt}$. \%.

The content of PGE in chromitites and dunites was determined in the rocks using the ICP-MS microprobe and kinetic methods, along with pre-concentration (nickel matte), at the TsNIGRI analytical laboratory (Moscow, Russia). The ICP-MS microprobe method with pre-concentration (nickel matte) involves melting the probe $(50 \mathrm{~g})$ at $1100{ }^{\circ} \mathrm{C}$, during which two phases are formed: A sulfide (nickel matte) and an oxide (skimming) phase. These phases are segregated according to the concentration of all noble elements in nickel matte. The collector is an alloy of sulfides and a metal alloy, in which the bulk of the noble metals is collected [27]. The received matte is cleaned through skimming and crushed for 10-15 s. A portion of the matte is dissolved in hydrochloric acid, while the Ni and $\mathrm{Cu}$ of the matte are almost completely dissolved. Platinum metals in the nonsolute residue are dissolved in a mixture of hydrochloric and nitric acids. The mass concentration of $\mathrm{Pt}, \mathrm{Pd}, \mathrm{Rh}, \mathrm{Ru}$, and Ir in the solution is determined by ICP-MS. Osmium is separated from other noble metals by distillation. The method is based on the ability of osmium to form volatile tetraoxides under oxidizing conditions [28]. The determination of the osmium concentration was carried out using a kinetic method. The method is based on the catalytic effect of osmium in indicator oxidation-reduction reactions. The reaction rate depends on the concentration of the catalyst [28-30]. The detection limits were 2 ppb for Os, Ir, Ru, and Rh; and $5 \mathrm{ppb}$ for Pt and Pd.

The studied platinum-group minerals were polished plates (21 pieces) and heavy fractions, extracted from chromite ores. The selected PGM grains were mounted in epoxy blocks and polished with a diamond paste for further analysis. Microtextural observations of PGM were performed by means of reflected-light microscopy. The chemical composition of PGMs was determined using a MIRA 3 LMU scanning electron microscope, with an attached INCA Energy 450 XMax 80 microanalysis energy dispersive system, at the Sobolev Institute of Geology and Mineralogy, Russian Academy of Science, Novosibirsk, Russia (Analytical Center, IGM SB RAS). Pure metals were used as the standards to determine the chemical composition of the PGE, Ni, and $\mathrm{Cu}$; arsenopyrite was used for As; and pyrite was used for Fe. The minimum detection limits of the elements (wt. \%) were found to be $0.1-0.2$ for $S$, $\mathrm{Fe}, \mathrm{Co}, \mathrm{Ni}$, and $\mathrm{Cu} ; 0.2-0.4$ for $\mathrm{As}, \mathrm{Ru}, \mathrm{Rh}, \mathrm{Pd}, \mathrm{Sb}$, and Te; and 0.4-0.7 for Os, Ir, and Pt. 


\section{Geological Setting}

The ophiolite complexes are widely distributed in the south-eastern part of Eastern Sayan (Siberia, Russia) (Figure 1).

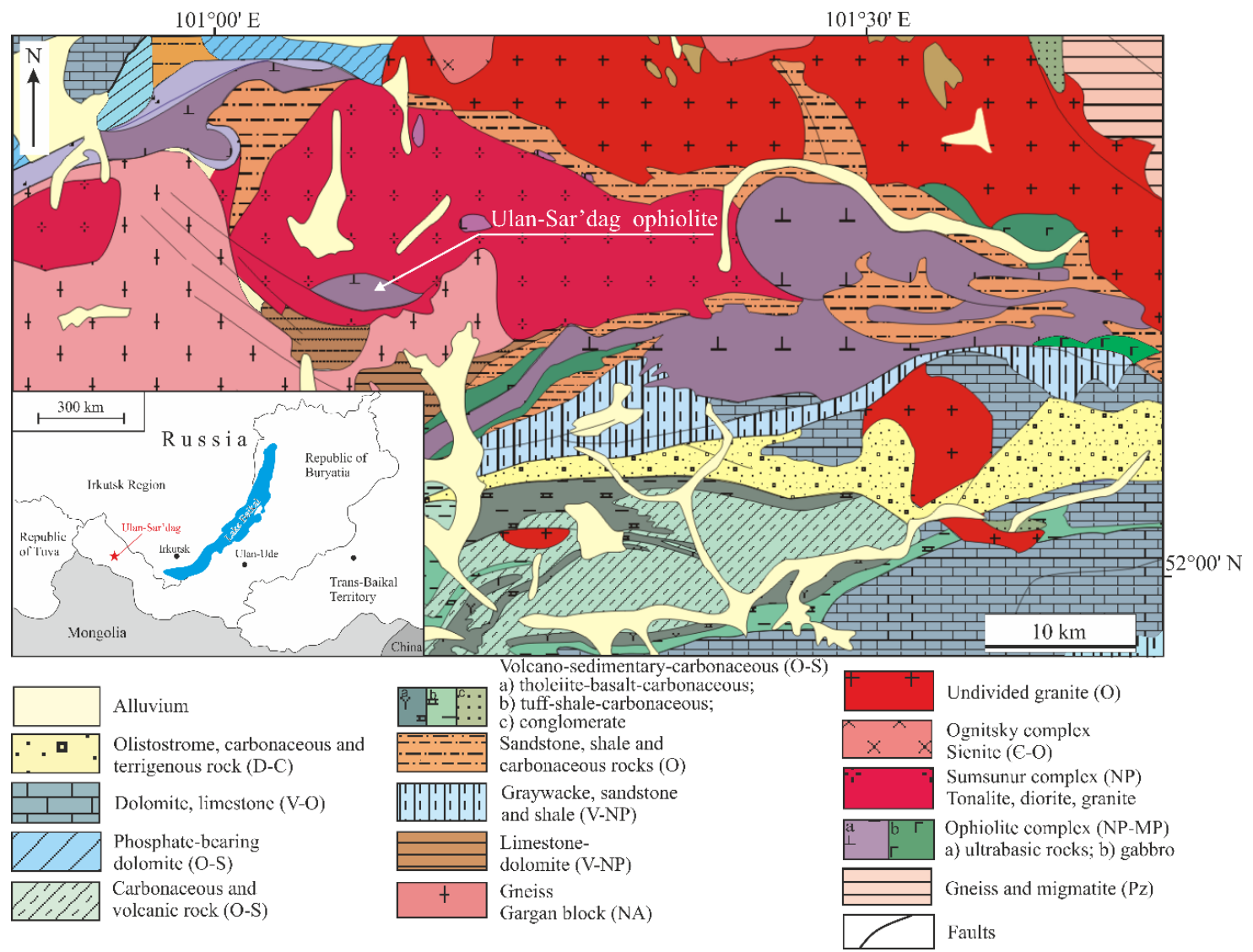

Figure 1. Geological map of the southeastern part of the Eastern Sayan region [31]. NB-northern branch, SB-southern branch.

The ophiolites are localized in the form of extended branches in the south (Il'chir) and north (Holbin-Hairhan). The features of these ophiolites are as follows: rock associations, geochemical and mineralogical characteristics, a geological structure resembling individual "massifs", geodynamic conditions and a formation time, which are actively studied for a considerable time. Dobretsov and Zhmodik et al. obtained data on the heterogeneity of ophiolites of the south-eastern part of Eastern Sayan (SEPES) [32,33]. They indicate that the ophiolites of the southern branch were formed in a mid-ocean ridges setting, and ophiolites of the northern branch were formed in an island arc setting [32-38]. The Ulan-Sar'dag ophiolite (USO) occupies a special structural position in the Eastern Sayan and Central Asian Fold Belt (Dunzhugur island arc). The USO is a tectonic plate, which is located between ophiolites of the southern and northern branches of the Dunzhugur island arc, near the contact zone of the Gargan "block" gneisses, with granites of the Sumsunur complex. The USO is underlaid by volcanogenic and sedimentary rocks of the Ilchir suite and limestones of the Irkut suite. Ophiolites include mantle restites (dunites, harzburgites), podiform chromitites, cumulates (metawehrlite, metapyroxenite, metagabbro), a basic dike and a volcanic complex (Ilchir suite) (Figures 2 and 3). USO has a lenticular body that is elongated in the east-west direction and is $1.5 \times 5 \mathrm{~km}^{2}$. It is composed of dunites and harzburgites. Harzburgites predominate in the central part, dunites and serpentinites prevail in the margin, and the latter lie in contact with the volcanogenic-sedimentary sequence of the Ilchir suite. The rocks of the cumulative series are metamorphosed under the conditions of epidote-amphibolite and amphibolite facies. The volcanogenic-sedimentary sequence 
is composed of volcanic, volcanogenic-sedimentary, and metasedimentary rocks (black schists and marbles). Volcanogenic-sedimentary rocks are sulfurized, and sulfide mineralization is confined to the schistosity zones. High-Ti basalts (MORB tholeiites), boninites, and island-arc andesites are distinguished in the volcanic complex. All rocks in the ophiolite nappe bottom are intensively deformed and mark the thrust zone. They include numerous crushing zones, signs of shear displacement and gliding planes. In the contact zone of serpentinites and rocks of the Ilchir suite, the talcum powder zones and zones of actinolite-tremolite composition are widely manifested.

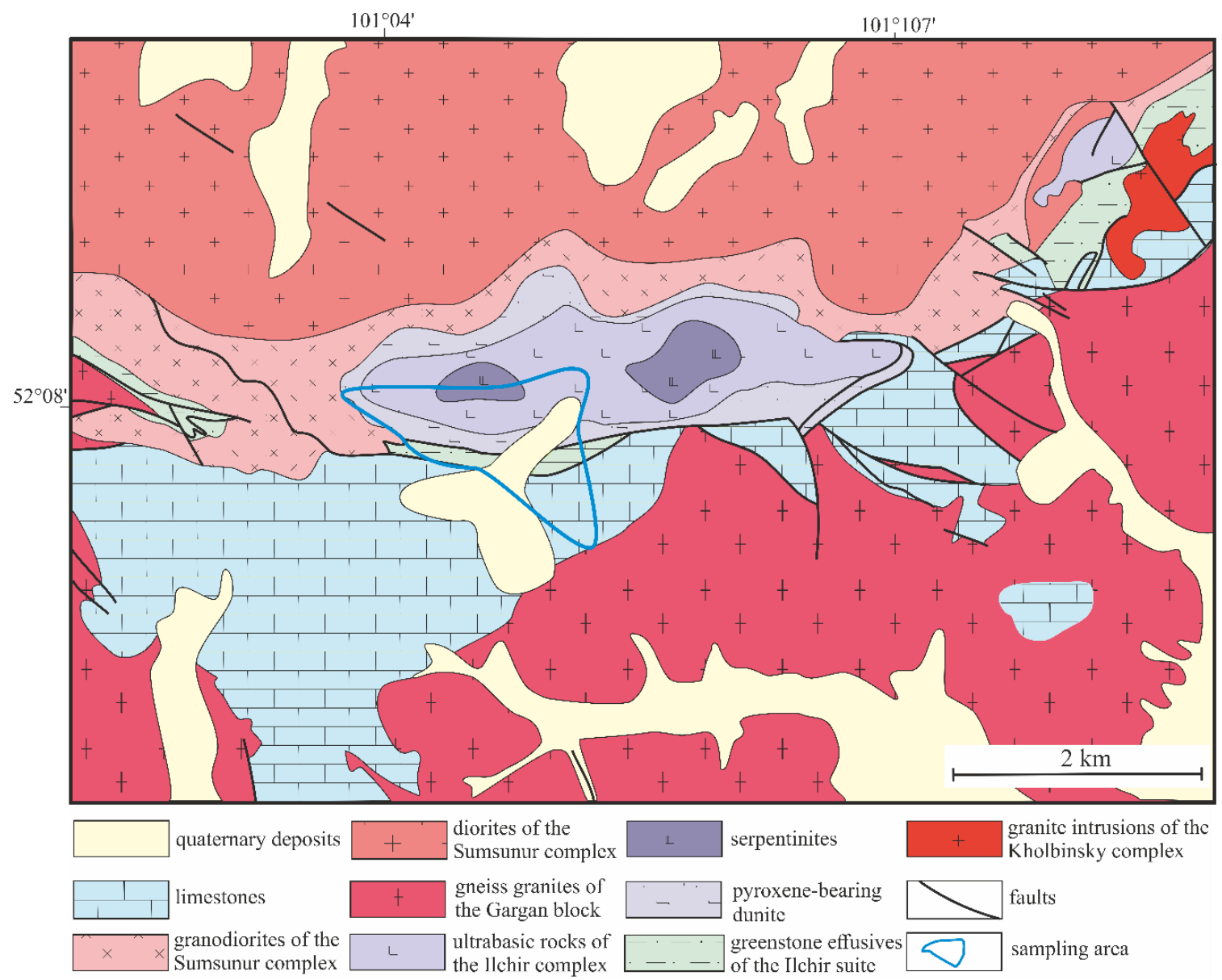

Figure 2. Geological scheme of the Ulan-Sar'dag ophiolite [39] with author additions.

The types of schlieren, lenticular, and vein-like chromite bodies are localized in dunites and serpentinites (Figure 4). The length of schlieren and massive chromitite bodies ranges from a few centimeters to several meters, and their width varies from $5 \mathrm{~cm}$ to $0.5 \mathrm{~m}$. The predominant structural-textural type is a massive chromitite. In some schlieren chromitites, the tectonic flow structures (Figure 4e) and the "snowball" type (Figure 4f) are observed. 

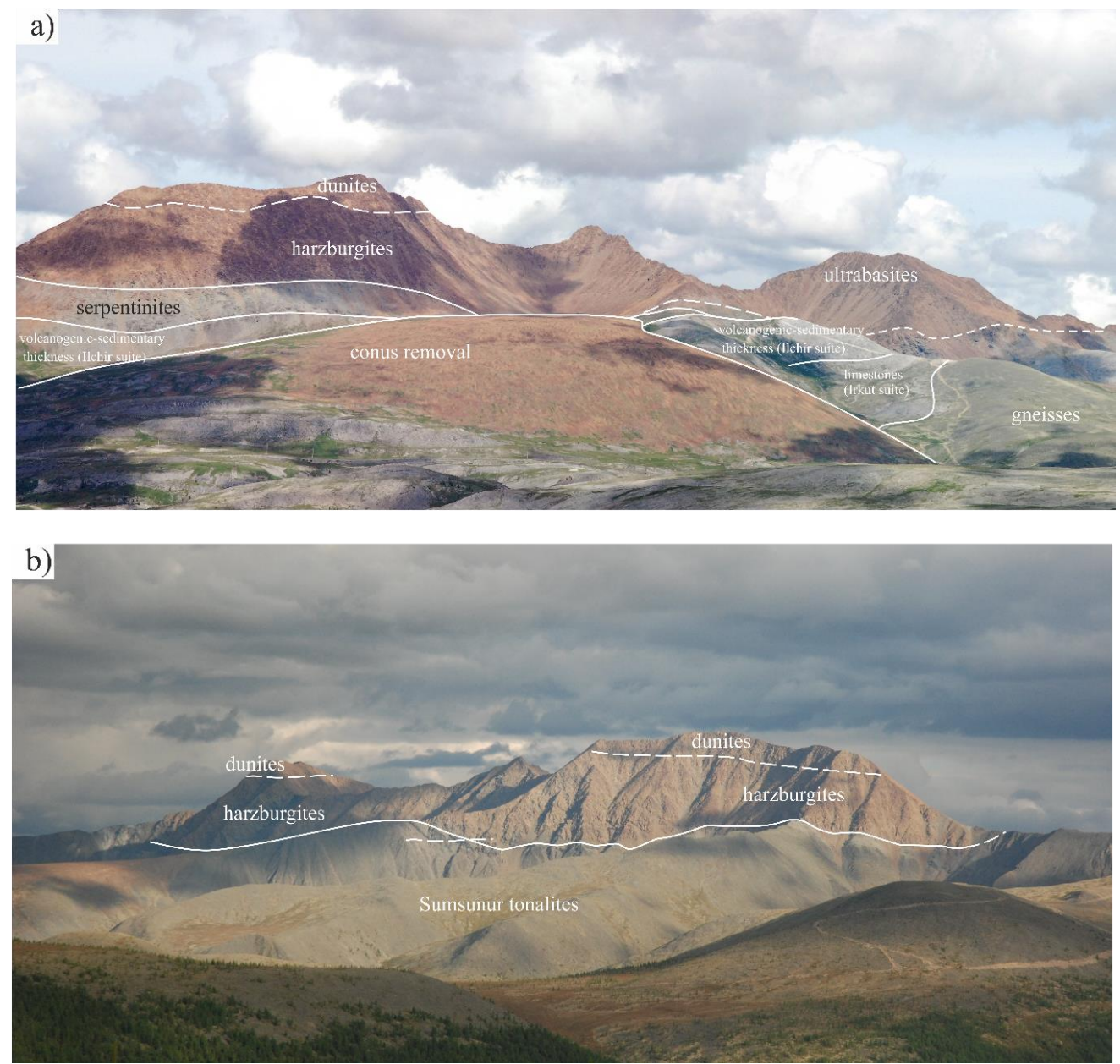

Figure 3. Photographs of the field relationship between mantle peridotites and volcanic-sedimentary rocks (Ilchir suite), limestone thickness (Irkut suit), Gargan gneisses, and Susunur tonalities: (a) view of the south side of the Ulan-Sar'dag ophiolite, (b) view of the north side of the Ulan-Sar'dag ophiolite.
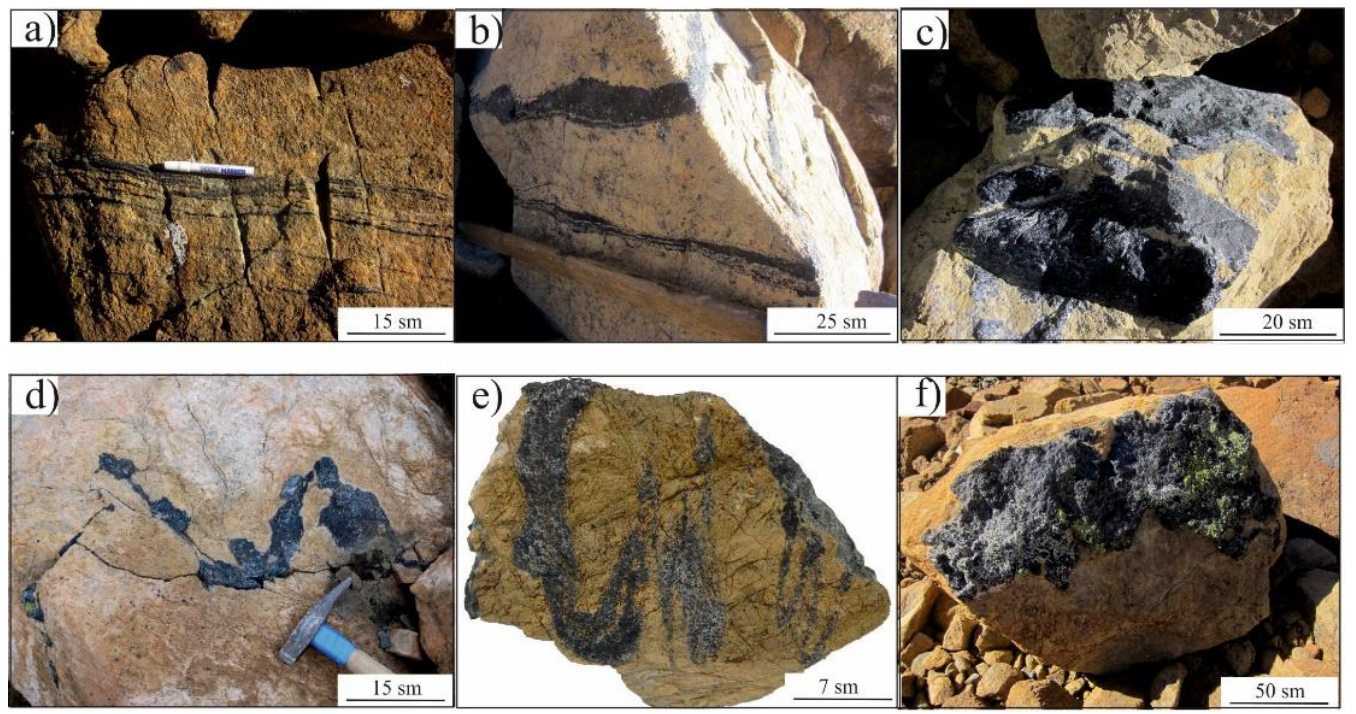

Figure 4. Structural features of chromitite pods: (a) chromitite seams in dunites; (b) schlieren; (c) massive pods; (d) transformation of the schlieren type into the massive type due to deformation processes; (e) folded schlieren-type chromitites; (f) structure of the "snowball". 


\section{Results}

\subsection{Podiform Chromitites}

Massive chromitites are the predominant petrographic variety of rocks in the mantle peridotites of the USO; disseminated, schlieren, and rhythmically-banded ores are less common. Chrome spinels make up 80-95 vol. \% of massive chromitites. The intergranular space is filled with olivine and secondary silicates: serpentine, chlorite, and, rarely, talc. The structure of massive chromitites varies from fine-grained to coarse-grained. The crystal bodies vary from subidiomorphic grains $(0.1-0.5 \mathrm{~cm})$ to allotrimorphic aggregates of grains of up to $1.5 \mathrm{~cm}$ in size. Chrome spinels have a cataclastic texture, and they are partially fragmented. The grains are dissected by cracks filled with secondary silicates. In the central part, chrome spinels are unchanged, and in cracks and on the grain rims, they are often replaced by chrome magnetite. Some grains contain olivine inclusions. A wide range of minerals show accessory mineralization in chromite ores: PGMs, sulfides, sulfarsenides, and sulfosalts of base metals (Figure 5).

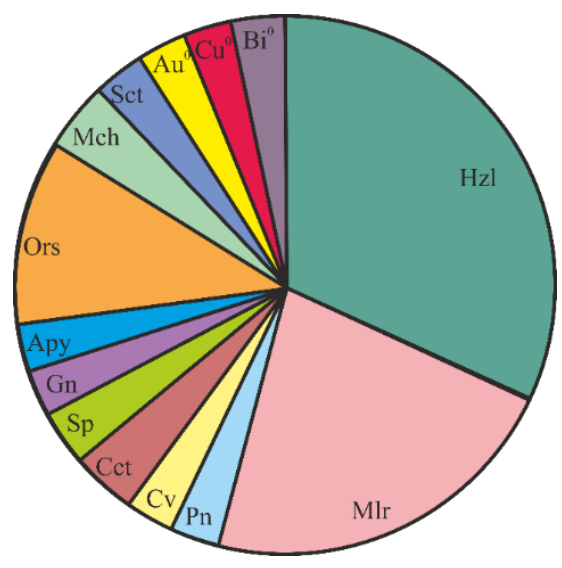

Figure 5. Accessory mineral association in chromitites. Hzl-heazlewoodite $\mathrm{Ni}_{3} \mathrm{~S}_{2} ; \mathrm{Mlr}-$ millerite NiS; Pn—pentlandite $(\mathrm{Fe}, \mathrm{Ni})_{9} \mathrm{~S}_{8}$; $\mathrm{Cv}$-covellite CuS; Cct—chalcocite $\mathrm{Cu}_{2} \mathrm{~S}$; Orc-orcelite $\mathrm{Ni}_{5} \mathrm{As}_{2}$; $\mathrm{Mh}-$ maucherite Ni11As 8 ; Sct—scutterudite $\mathrm{Co}_{4}\left(\mathrm{As}_{4}\right)_{3} ; \mathrm{Apy}$-arsenopyrite FeAsS; Sp—sphalerit ZnS; $\mathrm{Gn}$-galena $\mathrm{PbS} ; \mathrm{Au}^{0}, \mathrm{Cu}^{0}, \mathrm{Bi}^{0}$ —native gold, copper and bismuth.

\subsubsection{Chrome Spinels}

According to the chemical composition, ore chrome spinels are divided into three groups and are represented by chrome picotite, alumo-chromite, chromite, chrome-magnetite and magnetite (Table 1 , Figure 6). In one sample, chrome spinels of all three groups may be present. Chrome spinels of groups I, II, and III have the following compositions (wt. \%): $\mathrm{Al}_{2} \mathrm{O}_{3}=(17-43)$, (7-16), and (9-18); $\mathrm{Cr}_{2} \mathrm{O}_{3}=(26-54),(46-66)$, and (47-57); $\mathrm{MgO}=(10-20),(9-13)$, and (8-10); and $\mathrm{FeO}=(6-14),(1-18)$, and (18-20), respectively. In chromitites of the USO, chrome picotites are found, which is typical only of this massif, in contrast to chrome spinels from other ophiolite complexes of the southeastern part of East Sayan [38]. Chrome spinels have a homogeneous composition. Altered chrome spinels demonstrate increased contents of $\mathrm{FeO}, \mathrm{MnO}, \mathrm{NiO}, \mathrm{ZnO}$, and $\mathrm{Fe}_{2} \mathrm{O}_{3}$ and decreased contents of $\mathrm{Cr}_{2} \mathrm{O}_{3}$ and $\mathrm{Al}_{2} \mathrm{O}_{3}$. Chrome spinels are often replaced by chrome magnetite and magnetite along the cracks. 
Table 1. Representative chemical composition of $\mathrm{Cr}$ spinels and the calculated parental melt composition (wt. \%) of Cr spinels. Thermometric and oxybarometric data for Cr spinels.

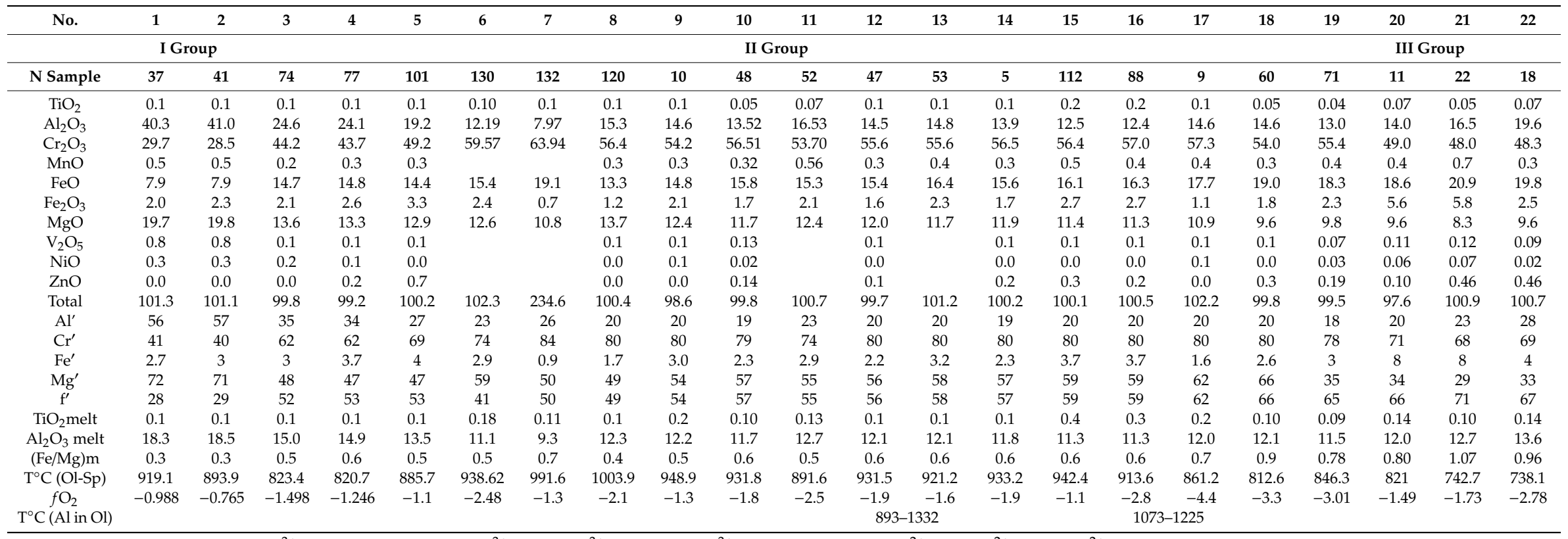

Notes: $\mathrm{Al}^{\prime}=\mathrm{Al} /\left(\mathrm{Al}+\mathrm{Cr}+\mathrm{Fe}^{3+}\right) ; \mathrm{Cr}^{\prime}=\mathrm{Cr} /\left(\mathrm{Cr}+\mathrm{Al}+\mathrm{Fe}^{3+}\right) ; \mathrm{Fe}^{\prime}=\mathrm{Fe}^{3+} /\left(\mathrm{Cr}+\mathrm{Al}+\mathrm{Fe}^{3+}\right) ; \mathrm{Mg}^{\prime}=\mathrm{Mg} /\left(\mathrm{Mg}+\mathrm{Fe}^{2+}\right) ; \mathrm{f}^{\prime}=\mathrm{Fe}^{2+} /\left(\mathrm{Mg}+\mathrm{Fe}^{2+}\right) ; \mathrm{Sample} \mathrm{No}$. 1-5-Cr-spinels I; 6-18-Cr-spinels II;

19-22-Cr-spinels III; $\mathrm{T}^{\circ} \mathrm{C}(\mathrm{Ol}-\mathrm{Sp})$-olivine-spinel geothermometer; $f\left(\mathrm{O}_{2}\right)$-oxygen fugacity; $\mathrm{T}^{\circ} \mathrm{C}(\mathrm{Al}$ in $\mathrm{Ol})$ —olivine geothermometer. 


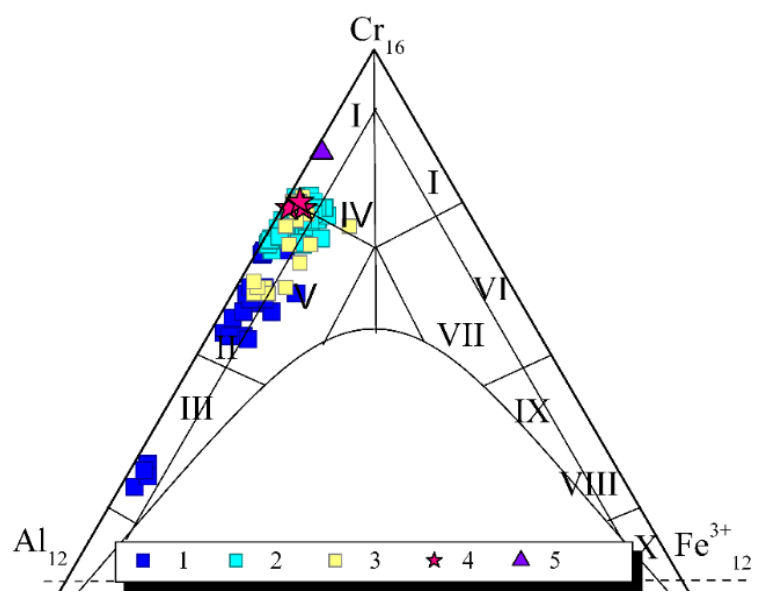

Figure 6. Classification diagram of chrome spinels from the chromitites of Ulan-Sar'dag, based on the structural formula of spinels. Composition fields: I-chromite; II-alumo-chromite; III-chrome picotite; IV-subferrichromite; V-subferrialumochromite; VI—ferrichromite; VII—subferrialumoferrichromite; VIII—chrome magnetite; IX—subalumochrome magnetite; X-magnetite [40]. Notes: 1—chrome spinels-I; 2-chrome spinels-II; 3-chrome spinels-III; 4—chrome spinels-II, with inclusions $(\mathrm{Os}, \mathrm{Ru}) \mathrm{S}_{2} ; 5$-chrome spinels-II, with olivine inclusion.

\subsubsection{Olivine}

Olivine in chromitites occupies the intergranular space of chrome spinels; it is often replaced by serpentine or chlorite. The data, which correspond to chrysotile and forsterite, are shown in Table 2. The $\mathrm{MgO}$ content is $49-54 \mathrm{wt}$. \%, and the $\mathrm{NiO}$ variations are insignificant and amount to $0.37-0.42 \mathrm{wt}$. \%, which corresponds to olivines from depleted peridotites. The fraction of the Fo component is 92-97.

Table 2. Chemical composition of the olivine from chromitites (wt. \%).

\begin{tabular}{|c|c|c|c|c|c|c|c|c|c|c|}
\hline N-Sample & $\mathrm{SiO}_{2}$ & $\mathrm{MgO}$ & $\mathrm{FeO}$ & $\mathrm{NiO}$ & $\mathrm{MnO}$ & $\mathrm{CaO}$ & $\mathrm{Al}_{2} \mathrm{O}_{3}$ & $\mathrm{Cr}_{2} \mathrm{O}_{3}$ & Total & Mg\# \\
\hline $298-1$ & 41.28 & 52.59 & 4.98 & 0.41 & 0.11 & 0.001 & & 0.002 & 99.38 & 95 \\
\hline 298-2 & 41.83 & 52.25 & 4.50 & 0.42 & 0.09 & 0.001 & & 0.002 & 99.08 & 95 \\
\hline $298-3$ & 41.26 & 52.20 & 5.68 & 0.42 & 0.12 & 0.002 & & 0.004 & 99.68 & 94 \\
\hline $298-4$ & 41.31 & 52.10 & 5.71 & 0.42 & 0.13 & 0.001 & 0.0118 & 0.002 & 99.68 & 94 \\
\hline 298-5 & 41.41 & 52.68 & 5.34 & 0.44 & 0.11 & 0.002 & 0.0052 & 0.002 & 99.98 & 95 \\
\hline $3-6$ & 41.08 & 51.19 & 6.95 & 0.37 & 0.11 & 0.001 & 0.0191 & 0.002 & 99.73 & 93 \\
\hline $3-7$ & 41.10 & 51.04 & 6.98 & 0.37 & 0.11 & 0.003 & 0 & 0.001 & 99.60 & 93 \\
\hline $3-8$ & 41.15 & 51.03 & 6.85 & 0.38 & 0.12 & 0.004 & 0.0119 & 0 & 99.54 & 93 \\
\hline $3-9$ & 40.83 & 50.85 & 7.13 & 0.38 & 0.13 & 0.015 & 0.0104 & 0.002 & 99.34 & 93 \\
\hline $3-10$ & 41.13 & 51.17 & 6.92 & 0.38 & 0.10 & 0.003 & 0.0015 & 0 & 99.69 & 93 \\
\hline $3-11$ & 41.22 & 51.02 & 6.89 & 0.37 & 0.11 & 0.004 & 0.0117 & 0.001 & 99.62 & 93 \\
\hline $3-12$ & 41.09 & 51.16 & 6.90 & 0.38 & 0.13 & 0.006 & 0.0005 & 0.001 & 99.66 & 93 \\
\hline $3-13$ & 41.07 & 51.19 & 6.89 & 0.37 & 0.13 & 0.005 & 0.0006 & & 99.65 & 93 \\
\hline $3-14$ & 41.10 & 51.08 & 6.93 & 0.37 & 0.10 & 0.006 & 0.0009 & & 99.58 & 93 \\
\hline $3-15$ & 41.24 & 51.26 & 6.79 & 0.38 & 0.13 & 0.009 & 0.003 & 0.002 & 99.80 & 93 \\
\hline $305-16$ & 41.33 & 53.61 & 3.28 & & & & & 0.61 & 98.83 & 97 \\
\hline $305-17$ & 41.38 & 53.86 & 3.45 & & & & & 0.69 & 99.38 & 97 \\
\hline $2-18$ & 41.05 & 51.71 & 6.47 & & & & & & 99.23 & 93 \\
\hline 973-19 & 40.25 & 50.24 & 8.14 & & & & & 0.01 & 98.64 & 92 \\
\hline $976-20$ & 41.43 & 51.26 & 6.90 & & & & & 0.02 & 99.61 & 93 \\
\hline $977-21$ & 40.09 & 50.39 & 6.85 & & & 0.02 & & 0.00 & 97.35 & 93 \\
\hline $939-22$ & 40.94 & 49.59 & 7.28 & & & 0.01 & & 0.03 & 97.85 & 92 \\
\hline $939-23$ & 40.74 & 49.06 & 9.61 & & & 0.04 & & 0.36 & 99.81 & 90 \\
\hline $970-24$ & 40.85 & 49.93 & 7.87 & & & 0.00 & & 0.02 & 98.67 & 92 \\
\hline $980-25$ & 42.39 & 53.59 & 5.50 & & & 0.01 & & 0.02 & 101.51 & 95 \\
\hline
\end{tabular}

Notes: (Samples 16-18)-inclusions in chromite. 


\subsection{Geochemistry of Platinum-Group Elements}

The content of PGE in mantle peridotites and podiform chromitites was determined. The content of PGE in dunites and serpentinites is 94-180 ppb; in chromitites, it ranges from 242 to $992 \mathrm{ppb}$ (Table 3). The PGE content increases with an increase in the volume percentage of chromite in the rock. In addition, depending on the proportion of the chromite and silicate components in the rock, the IPGE/PPGE ratio changes (Figure 7a,b) (IPGE: Os, Ir, and Ru; PPGE: Rh, Pt, and Pd). For example, in massive ores (85-95 vol. \% of chromite), IPGE > PPGE, and IPGE/PPGE = 0.86-2.15. In schlieren lenticular chromitites and chromitites with deformational textures, the PPGE proportion increases and amounts to IPGE/PPGE $=0.03-0.67$. In chromitites I, the IPGE/PPGE is higher than in chromitites II (Table 3).

Table 3. PGE abundance for the dunites and chromitites of the Ulan-Sar'dag ophiolite (ppb).

\begin{tabular}{cccccccccccc}
\hline No. & $\mathbf{1}$ & $\mathbf{2}$ & $\mathbf{3}$ & $\mathbf{4}$ & $\mathbf{5}$ & $\mathbf{6}$ & $\mathbf{7}$ & $\mathbf{8}$ & $\mathbf{9}$ & $\mathbf{1 0}$ & $\mathbf{1 1}$ \\
\hline N Sample & 6 & 305 & 6 mas & 7 mas & 294 mas & 307 mas & 6 mas & 3 mas & 17 mas & 20 mas & 2 shl \\
\hline Os & 6 & 8 & 45 & 51 & 58 & 117 & 49 & 37 & 81 & 46 & 7 \\
Ir & 21 & 6 & 26 & 58 & 43 & 82 & 57 & 20 & 35 & 20 & 6 \\
Ru & 7 & 14 & 68 & 53 & 116 & 221 & 121 & 59 & 44 & 46 & 20 \\
Rh & 7 & 3 & 12 & 10 & 8 & 19 & 24 & 16 & 9 & 11 & 21 \\
Pt & 35 & 15 & 39 & 49 & 31 & 54 & 49 & 64 & 46 & 41 & 35 \\
Pd & 104 & 48 & 177 & 182 & 104 & 122 & 478 & 97 & 87 & 78 & 903 \\
Total & 180 & 94 & 367 & 403 & 360 & 615 & 778 & 293 & 302 & 242 & 992 \\
Pt/Ir & 1.67 & 2.5 & 1.5 & 0.84 & 0.72 & 0.66 & 0.86 & 3.20 & 1.31 & 2.05 & 5.83 \\
$\sum$ IPGE & 34 & 28 & 139 & 162 & 217 & 420 & 227 & 116 & 160 & 112 & 33 \\
$\sum$ PPGE & 146 & 66 & 228 & 241 & 143 & 195 & 551 & 177 & 142 & 130 & 959 \\
IPGE/PPGE & 0.23 & 0.42 & 0.61 & 0.67 & 1.52 & 2.15 & 0.41 & 0.66 & 1.13 & 0.86 & 0.03 \\
IPGE & 180 & 94 & 367 & 403 & 360 & 615 & 778 & 293 & 302 & 242 & 992 \\
Cr\# (Crt) & & & 68 & 67 & 65 & 57 & 70 & 69 & 84 & 83 & 75 \\
Al\#(Crt) & & & 30 & 30 & 42 & 34 & 26 & 27 & 14 & 15 & 22 \\
\hline
\end{tabular}

Notes: 1,2-dunites; 3-11-chromitites. mas-massive pods, shl-shlieren pods; 3-6-group I chromitites; 7-10—group II chromitites; 11—group III chromitite.
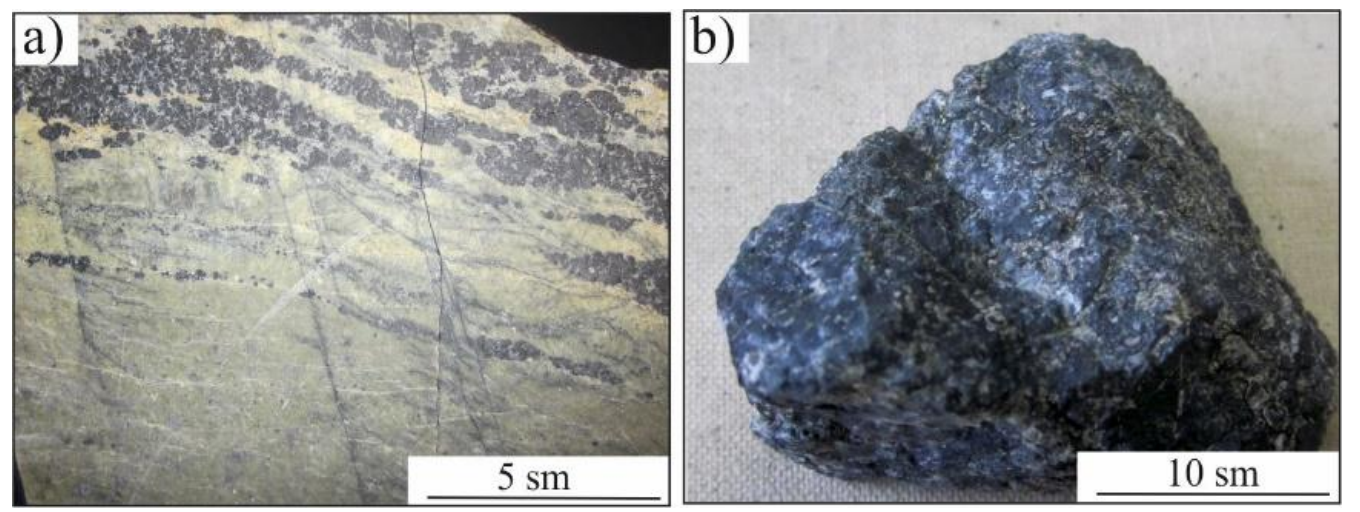

Figure 7. Photographs of chromitites with different values of IPGE/PPGE: (a) schlieren densely disseminates in serpentinizated dunite $\left(\sum \mathrm{PGE}=903 \mathrm{ppb}\right.$, and IPGE/PPGE $\left.=0.03\right)$; $(\mathbf{b})$ massive $\left(\sum \mathrm{PGE}=615 \mathrm{ppb}\right.$, and IPGE/PPGE $\left.=2.15\right)$.

\subsection{Mineralogy of Platinum-Group Elements}

The first data on PGE mineralization (PGM) in chromitites of USO have been obtained. The chemical composition of the minerals is presented in Table 4, and classification diagrams are presented in Figure 8a,b. Primary and secondary PGMs have been distinguished. The most common platinum-group minerals in the chromitites of the USO are PGE sulfides: laurite-erlichmanite $(\mathrm{Ru}, \mathrm{Os}) \mathrm{S}_{2}$, with different $\mathrm{Ru} /(\mathrm{Ru}+\mathrm{Os})$ ratios. Other PGE phases are represented by high-temperature Os-Ir-Ru alloys-I, phases of variable-composition Os-Ir-Ru alloys-II, native Os, Ru, sulfarsenides of (Os, Ir, Ru), and zaccarinite RhNiAs. The primary and secondary PGMs will be described separately. 
Table 4. Representative composition of platinum-group elements in the chromitite from the Ulan-Sar'dag ophiolitic massif.

\begin{tabular}{|c|c|c|c|c|c|c|c|c|c|c|c|c|c|c|c|c|c|c|c|c|c|c|}
\hline \multirow[t]{2}{*}{$\begin{array}{l}\text { No. } \\
\text { an }\end{array}$} & Os & Ir & $\mathbf{R u}$ & $\mathbf{R h}$ & $\mathrm{Fe}$ & $\mathrm{Ni}$ & $\mathrm{S}$ & As & $\mathrm{Sb}$ & O & Total & Os & Ir & $\mathbf{R u}$ & $\mathbf{R h}$ & $\mathrm{Fe}$ & $\mathrm{Ni}$ & $\mathrm{S}$ & As & $\mathrm{Sb}$ & O & $\begin{array}{c}\mathrm{Ru} / \\
(\mathrm{Ru}+\mathrm{Os})\end{array}$ \\
\hline & wt. \% & \multicolumn{21}{|c|}{ apfu } \\
\hline 1 & 75.01 & 21.95 & 3.38 & & 0.72 & & & & & & 101.06 & 0.39 & 0.11 & 0.03 & & 0.01 & & & & & & \\
\hline 2 & 74.84 & 20.6 & 5.16 & & 0.33 & & & 0 & & & 100.93 & 0.39 & 0.11 & 0.05 & & 0.01 & & & & & & \\
\hline 3 & 79.75 & 20.74 & 2.35 & & 0.35 & & & & & & 103.19 & 0.41 & 0.1 & 0.02 & & 0.01 & & & & & & \\
\hline 4 & 23.87 & 5.23 & 34.23 & & 0.59 & & 33.36 & & & & 97.28 & 0.24 & 0.05 & 0.65 & & 0.02 & & 2 & & & & 0.59 \\
\hline 5 & 23.21 & 5.18 & 39.55 & 0.6 & & & 34.33 & & & & 102.87 & 0.23 & 0.05 & 0.73 & 0.01 & 0.00 & & 2 & & & & 0.63 \\
\hline 6 & 33.29 & 5.5 & 27.26 & & 0.58 & & 31.27 & & & & 97.9 & 0.36 & 0.06 & 0.55 & & 0.02 & & 2 & & & & 0.45 \\
\hline 7 & 22.92 & 4.3 & 39.85 & & & & 35.23 & & & & 102.3 & 0.22 & 0.05 & 0.73 & & & & 2 & & & & 0.63 \\
\hline 8 & 20.65 & 6.86 & 39.48 & & & & 33,15 & & & & 100.14 & 0.21 & 0.07 & 0.75 & & & & 2 & & & & 0.66 \\
\hline 9 & 8.94 & 5.76 & 50.87 & & & & 37.82 & & & & 103.39 & 0.08 & 0.05 & 0.85 & & & & 2 & & & & 0.85 \\
\hline 10 & 33.62 & 2.93 & 34.3 & & & & 32 & 0.66 & & & 103.51 & 0.35 & 0.03 & 0,67 & & & & 1.98 & 0.02 & & & 0.51 \\
\hline 11 & 49.97 & 2.18 & 20.8 & & & & 30.12 & & & & 103.07 & 0.56 & 0.02 & 0.44 & & & & 2.00 & & & & 0.29 \\
\hline 12 & & 3.5 & 58.59 & & & & 38.19 & 1.67 & & & 101.95 & & 0.03 & 0.95 & & & & 1.96 & 0.04 & & & 1 \\
\hline 13 & & & 62.81 & & & & 39.43 & & & & 102,24 & & & 1.01 & & & & 2 & & & & 1 \\
\hline 14 & 1.91 & 4.45 & 57.45 & & 0,32 & 0.49 & 36.31 & 0.92 & & & 101,85 & 0.02 & 0.04 & 0,99 & & 0,01 & 0.01 & 1.98 & 0.02 & & & 0.97 \\
\hline 15 & 92.73 & 0 & 8.57 & & & 0.47 & 1.2 & 0.19 & & & 103.16 & 0.79 & & 0.14 & & 0,00 & 0.01 & 0.06 & & & & \\
\hline 16 & 37.98 & 31.17 & 29.55 & & 0.88 & 1.61 & & & & & 101.19 & 0.29 & 0.23 & 0.42 & & 0.02 & 0.04 & & & & & \\
\hline 17 & 28.79 & 27.29 & 37.06 & 4.4 & 0.71 & & 1.15 & & & & 99.4 & 0.21 & 0.2 & 0.51 & 0.06 & 0.02 & & & & & & \\
\hline 18 & 33.33 & 11.19 & 53.61 & & & & & & & 2.12 & 100.25 & 0.19 & 0.06 & 0.6 & & & & & & & 0.14 & \\
\hline 19 & 34.25 & 9.51 & 54.3 & & & & 1.57 & & & 3.19 & 102.82 & 0.17 & 0.05 & 0.54 & & & & 0.05 & & & 0.19 & \\
\hline 20 & 88.01 & 11.34 & & & 1.09 & 2.01 & & 0.2 & & 0.66 & 103.31 & 0.8 & 0.1 & & & 0.03 & 0.06 & & & & & \\
\hline 21 & 59.46 & 16.78 & 21.62 & & 0.58 & 3.06 & & & & & 101.5 & 0.46 & 0.13 & 0.32 & & 0.01 & 0.07 & & & & & \\
\hline 22 & 2.52 & 2.11 & 93.14 & & & 2.55 & & & & & 100.32 & 0.01 & 0.01 & 0.93 & & & 0.04 & & & & & \\
\hline 23 & 3.01 & 3.67 & 52.84 & & & 0.99 & 36.78 & 3.3 & & & 100.59 & 0.03 & 0.03 & 0.88 & & & 0.03 & 1.93 & 0.07 & & & 0.95 \\
\hline 24 & & & 60.54 & & 0.32 & 0.46 & 38.33 & & & & 99.65 & & & 1 & & 0.01 & 0.01 & 2 & & & & 1 \\
\hline 25 & 47.44 & 4.97 & 22.55 & & 0.37 & & 27.28 & & & & 102.61 & 0.59 & 0.06 & 0.52 & & 0.02 & & 2 & & & & 0.32 \\
\hline 26 & & & 60.93 & & & & 38.64 & & & & 99.57 & & & 1 & & & & 2 & & & & 1 \\
\hline 27 & 9.25 & 3.47 & 54.02 & & & & 34.92 & & & & 101.66 & 0.09 & 0.03 & 0.98 & & & & 2 & & & & 0.85 \\
\hline 28 & 60.28 & 6.17 & 6.88 & & 0.37 & 1.04 & 23.79 & & & & 98.53 & 0.85 & 0.09 & 0.18 & & 0.02 & 0.05 & 2 & & & & 0.1 \\
\hline 29 & & & 59.89 & & 0.46 & & 37.67 & & & & 98.02 & & & 1.01 & & 0.01 & & 2 & & & & 1 \\
\hline 30 & & 58.69 & 2.1 & 2.31 & & & 12.51 & 23.25 & & & 98.86 & & 0.29 & 0.02 & 0.02 & & & 0.37 & 0.30 & & & \\
\hline 31 & 1.18 & 59.23 & 1.44 & 0.35 & & 0.81 & 11.38 & 24.82 & & & 99.21 & 0.03 & 0.41 & 0.1 & & & & 0.63 & 0.37 & & & \\
\hline 32 & 1.8 & 56.58 & 5.84 & 0.6 & & & 12.85 & 19.07 & 1 & & 97.74 & 0.01 & 0.29 & 0.06 & 0.01 & & & 0.39 & 0.25 & 0.01 & & \\
\hline 33 & & 48.23 & 11.47 & 3.91 & & & 16.81 & 20.93 & & & 101.35 & & 0.21 & 0.09 & 0.03 & & & 0.44 & 0.23 & & & \\
\hline 34 & & 61.04 & 2.53 & 0.87 & & & 11.81 & 23.78 & 1.16 & & & & 0.30 & 0.02 & 0.01 & & & 0.35 & 0.30 & 0.01 & & \\
\hline 35 & 4.21 & 3.15 & 10 & 37.77 & & 22.35 & & 25.66 & & & 103.14 & 0.02 & 0.01 & 0.08 & 0.3 & & 0,31 & & 0.28 & & & \\
\hline 36 & 21.34 & 10.58 & 26.92 & 0.57 & & 28.95 & 6.5 & 14.23 & & & 109.09 & 0.17 & 0.08 & 0.40 & 0.01 & & 0.74 & 0.31 & 0.29 & & & \\
\hline
\end{tabular}

Notes: Primary high temperature PGM: Os-Ir-Ru alloys-I—(1-3); laurite I—(4-7); altered laurite II—(8-14); secondary PGM: Os-Ir-Ru alloys-II—(15-22); laurite III—(23-29); irarsite—(30-34); RhNiAs-35; (Ru,Ni,Os,Ir,Rh)AsS-36. 

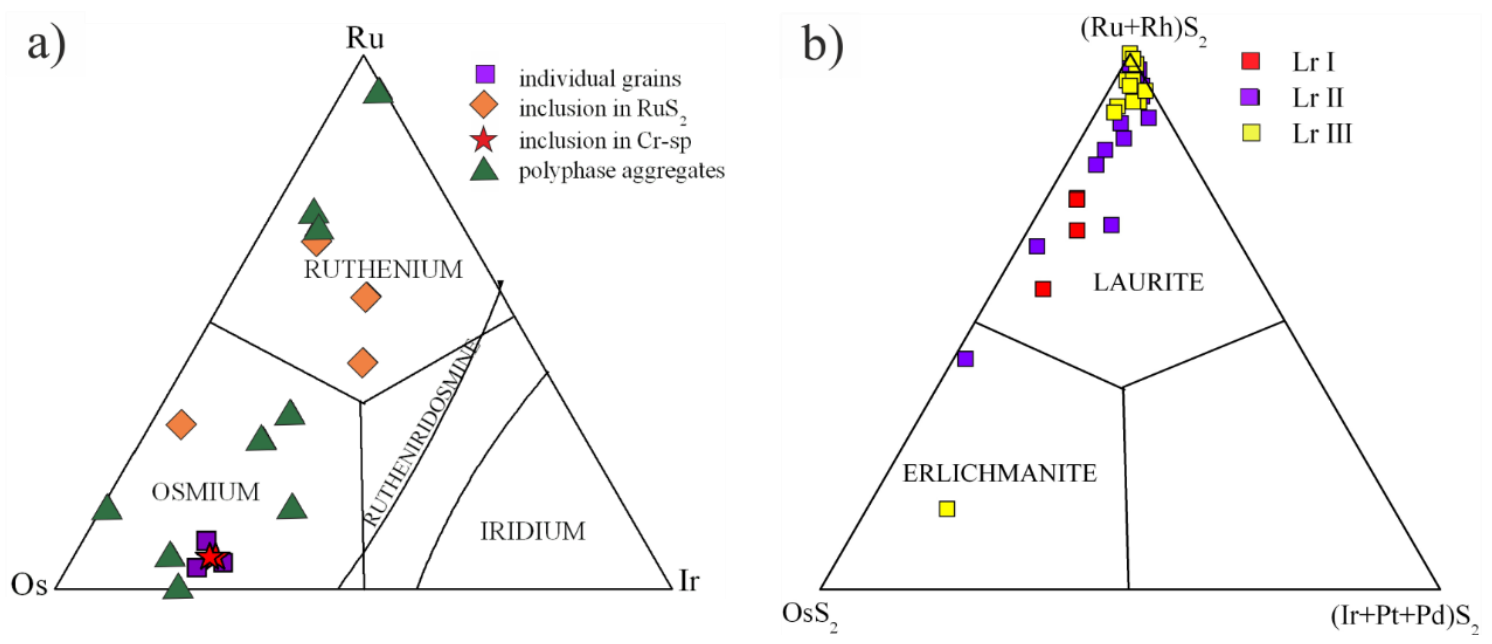

Figure 8. Diagram of the compositions of PGE minerals: (a) Os-Ir-Ru alloys; (b) Laurite-erlichmanite: Lr I-primary, inclusion in chrome spinels or isolated grains, laurite II-primary altered sulfides, and laurite III—secondary sulfides. The fields shown in the diagrams are drawn from [41].

\subsubsection{Primary Platinum-Group Minerals}

High-temperature Os-Ir-Ru alloys-I are in the form of idiomorphic inclusions in chrome spinels, and xenomorphic grains are intergrown with laurite. Single grains contain inclusions of $(\mathrm{Ru}, \mathrm{Os}) \mathrm{S}_{2}$ of less than $10 \mu \mathrm{m}$ in size. The alloys are enriched with Os, and its content varies from 71 to $79 \mathrm{wt}$. \%; the content of Ir ranges from 20 to $28 \mathrm{wt}$. \%; and the content of Ru is very low and ranges from 2 to $5 \mathrm{wt}$. \%. There are some impurities of Fe and Ni. In the classification diagram, the compositions of the primary alloys correspond to osmium with low contents of Ir and Ru (Figure 8a). Dissolution microstructures are observed in some grains (Figure 9).

\section{Laurite-Erlichmanite (Ru,Os) $\mathrm{S}_{2}$}

Sulfides can be divided into two groups, according to their composition and microstructural features (Table 4). The first group, laurite I, contains laurite-erlichmanite with a homogeneous composition.

Laurite-erlichmanite occurs as an inclusion in chrome spinels $(10-15 \mu \mathrm{m})$, and in some cases, it can be intergrown with amphibole (magnesio-hastingsite hornblende) in chrome spinel or be found as individual grains (Figure 9c,d). The ratio, $\mathrm{Ru}^{\prime}=\mathrm{Ru} /(\mathrm{Ru}+\mathrm{Os}$ ), is $0.61-0.78$. The content of Os is $20-33 \mathrm{wt}$. \%, and Ru is $27-40 \mathrm{wt}$. \%. In the classification diagram, they are in the laurite field (Figure $8 \mathrm{~b}$ ). The second group, laurite II, contains laurites of a heterogeneous composition, containing micro inclusions of (Os-Ir-Ru) II alloys and laurites, which are replaced by PGE sulfarsenides (Figure 9e-g). Laurite II ( $\mathrm{Lr}$ II) is characterized by wide variations in the contents of Os of 1.2-49.9 wt. \%, Ru of 20.8-62.2 wt. \%, and the $\mathrm{Ru} /(\mathrm{Ru}+\mathrm{Os})$ ratio of $0.44-0.99$. In the classification diagram, they are in the fields of erlichmanite and laurite. In the chemical composition of laurite, a sulfur deficiency is often registered (Table 4). Insignificant amounts of irarsite IrAsS are found in the chromitites of the USO, where it replaces laurite. Irarsite forms corrosive, looped structures to replace laurite (Figure 9g,h). 

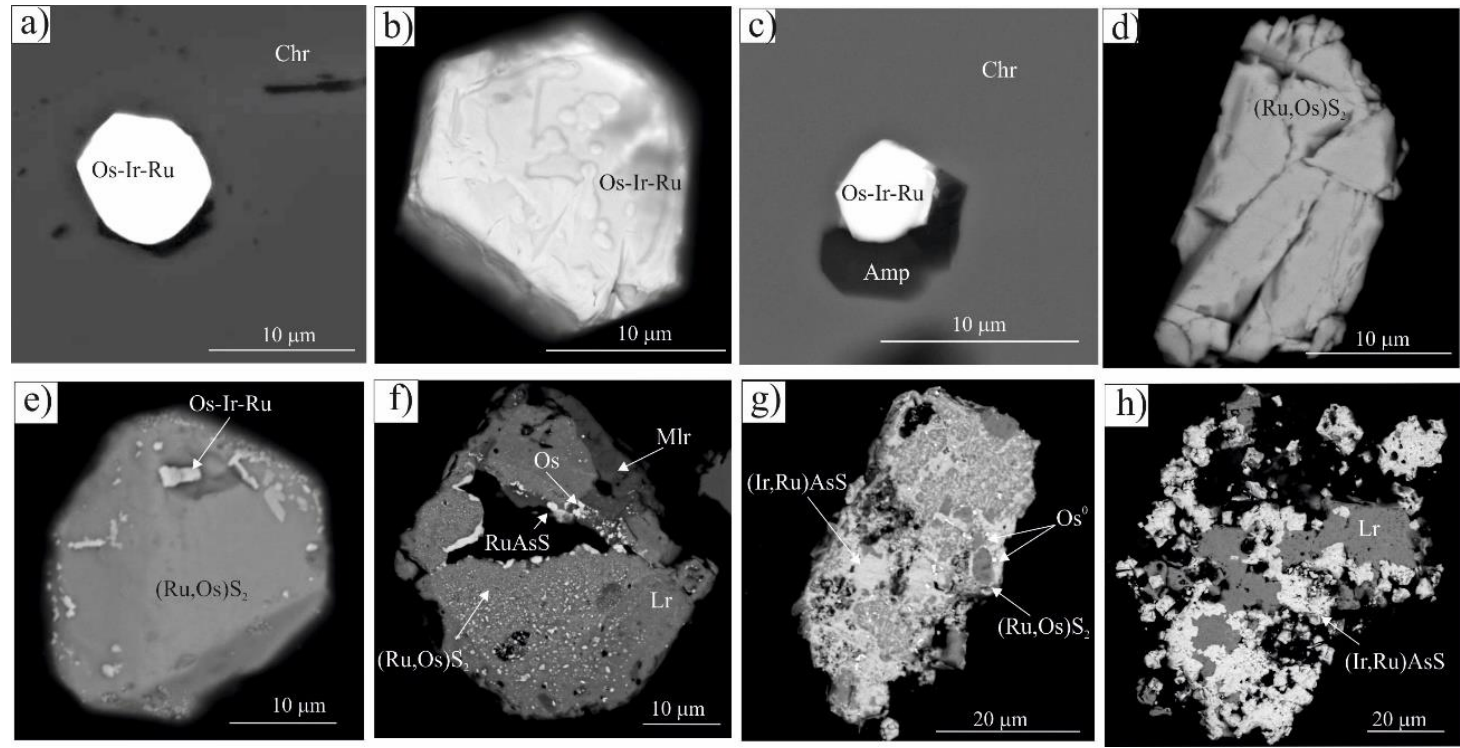

Figure 9. Back Scattered Electron (BSE) images of primary PGM, showing the textural and morphological relations of single and polyphase PGM from the Ulan-Sar'dag chromitites: (a) inclusion euhedral Os-Ir-Ru alloy-I in chromite, an. 1; (b) individual single-grain Os-Ir-Ru alloys-I, with a dissolution microstructure, an. 2; (c) inclusion in Cr-spinel of intergrowth laurite I and hornblende, an. 6; (d) individual grain of laurite I, an. 7; (e) grain of laurite II (an. 8), with inclusions of micro particle Os-Ir-Ru alloys-II; (f) grain laurite II (an. 9), associated with an unnamed phase ( $\mathrm{Ru}, \mathrm{Ni}, \mathrm{Os}, \mathrm{Ir}, \mathrm{Rh}) \mathrm{AsS}$ (an. 36) (laurite II is surrounded by Os-poor laurite, which grows with millerite); (g) substitution of laurite II by irarsite (an. 32), with remnants of laurite II (an. 10,11) and Os-Ir-Ru alloys-II; (h) laurite II (an. 12) surrounded by irarsite (an. 33). Abbreviations: Crsp—chrome spinel; Lr-laurite; Mlr-millerite. Notes: an. No-No analysis, as shown in Table 4.

\subsubsection{Secondary Platinum-Group Minerals}

The secondary PGMs are presented by $(\mathrm{Os}, \mathrm{Ru}) \mathrm{S}_{2}$-laurite III, native Os and $\mathrm{Ru}$, Os-Ir- $\mathrm{Ru}$ alloys-II of a variable composition, irarsite IrAsS, zaccarinite $\mathrm{RhNiAs}$, and ( $\mathrm{Ru}, \mathrm{Ni}, \mathrm{Os}, \mathrm{Ir}, \mathrm{Rh})(\mathrm{As}, \mathrm{S})$ sulfarsenides of a non-stoichiometric composition. The secondary phases are localized in the chloritized silicate intergranular space of chrome spinels. Some grains (micro particles of osmium and other phases) are very small (less than $2-3 \mu \mathrm{m}$ ), and their chemical composition can be determined only semi-quantitatively. In some cases, micro particles of a variable composition ( $\mathrm{Ru}, \mathrm{Ir}, \mathrm{Os}, \mathrm{Cu}, \mathrm{Te}, \mathrm{Ni}, \mathrm{Ba}, \mathrm{S}, \mathrm{O})$ can be found with secondary PGMs. Further, due to their very small size and partial coincidence with the elemental composition of the host mineral, qualitative analysis can also be hampered.

\section{Os-Ir-Ru Alloys-II}

Micro particles of Os-Ir-Ru alloys-II are the common phases and are found in a secondary mineral assemblage. They are localized mainly in laurite II, or they are a part of polyphase aggregates with $\mathrm{Ni}$, $\mathrm{Cu}$ sulfides, sulfarsenides of Os, Ir, and Ru, zaccarinite RhNiAs, and laurite III (Figure 10a-d). Their composition varies (Table 4, Figure 8a) from native osmium to native ruthenium. Native osmium is composed of (wt. \%): Os (87-92), Ir (0-12), and Ru (3-8). Native Ru is composed of (wt. \%): Ru (93), Os (2.5), and Ir (2.1). The composition of the (Os-Ir-Ru) II alloys varies, with a wide range (wt. \%): Os (30-74), Ir (6-32), and Ru (8-58). 

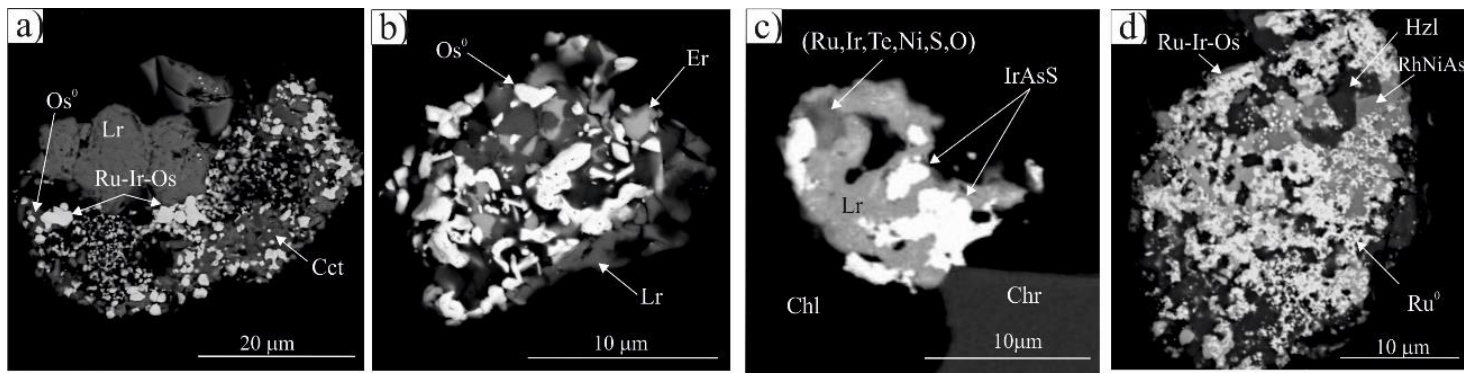

Figure 10. BSE images of secondary PGMs, showing the textural, morphological relations and assemblages of the PGM from the Ulan-Sar'dag chromitites: (a) intergrowth of laurite III (an. 26) and PGE bearing chalcocite $\mathrm{Cu}_{2} \mathrm{~S}$, with micro inclusions of Os-Ir-Ru alloys- II (an. 18); (b) polyphase aggregate of agglomeration PGM particles, consisting of Os-rich laurite III (an.28), native Os ${ }^{0}$ (an. 20), and Os-poor laurite III (an. 27); (c) composite grain of irarsite (an. 34), laurite III (an. 29), and unnamed phases ( $\mathrm{Ru}, \mathrm{Ir}, \mathrm{Te}, \mathrm{Ni}, \mathrm{S}, \mathrm{O})$ within the interstitial chlorite of chromitites; (d) polyphase aggregate, consisting of Os-Ir-Ru alloys-II (an. 21), $\mathrm{Ru}^{0}$ (an. 22), zaccarinite RhNiAs (an. 35), and heazlewoodite. Abbreviations: Chl—chlorite; Cct—chalcocite; Hzl—heazlewoodite; Irs—irarsite; Lr III-laurite III. Notes: an. No-No analysis, as shown in Table 4.

\section{Laurite III}

The occurrence forms of secondary laurite III are very diverse. It is mainly localized in Cr-containing chlorite, where it forms polyphase aggregates with PGE-containing chalcocite $\left(\mathrm{Cu}_{2} \mathrm{~S}\right)$ (Figure 10a), recrystallized PGM aggregates with native Os (Figure 10b), micro particles in association with $\mathrm{Ni}_{3} \mathrm{~S}_{2}, \mathrm{NiS}$ and phases of a non-stoichiometric composition ( $\left.\mathrm{Ru}, \mathrm{Ir}, \mathrm{Os}, \mathrm{Cu}, \mathrm{Te}, \mathrm{Ni}, \mathrm{Ba}, \mathrm{S}, \mathrm{O}\right)$ (Figure 10c). The following features are characteristic of laurite III: a) A porous structure, with Cr-bearing minerals of the chlorite group in the voids, and b) a very small grain size (micro particles). The chemical composition corresponds to the end member of the laurite-erlichmanite solid solution: $\mathrm{RuS}_{2}-\mathrm{OsS}_{2}$ (Figure 8b). Laurite III is characterized by very low Os and Ir contents and the absence of Rh. Sometimes it contains $\mathrm{Ni}$ impurities. The value of $\mathrm{Ru}^{\prime}$ varies insignificantly and amounts to $0.93-1$ (Table 4); in turn, $\mathrm{OsS}_{2}$ has low contents of $\mathrm{Ru}$ and $\mathrm{Ir}$ and is located in a recrystallized aggregate with laurite III and native Os (Figure 10b).

The (Ir,Os, Ru)AsS in the secondary association is in the form of polyphase aggregates. It replaces laurite. It contains Os and $\mathrm{Ru}$ in insignificant amounts. Secondary irarsite is presented as very small microparticles (less than $5 \mu \mathrm{m}$ ) in chlorite in association with $\mathrm{Ni}_{3} \mathrm{~S}_{2}$ and laurite III.

$(\mathrm{Ru}, \mathrm{Ni}, \mathrm{Os}, \mathrm{Ir}, \mathrm{Rh})(\mathrm{As}, \mathrm{S})$ is found in the form of micro particles $(7 \mu \mathrm{m})$ in a polyphase aggregate, consisting of laurite II and NiS (Figure 9f). There is a deficit of $S$ and As in this phase.

Zaccarinite $\mathrm{RhNiAs}$ is found in polyphase aggregates in association with $\mathrm{Ni}_{3} \mathrm{~S}_{2}$, secondary (Os-Ir-Ru) II alloys and native Ru (Figure 10d).

Unknown phase No. $1(\mathrm{Ir}, \mathrm{Ni}, \mathrm{Cu}, \mathrm{Ru}, \mathrm{Os}, \mathrm{Cl})$ is found in the intergrowth with laurite, erlichmanite, and chalcocite. This association is localized in chromite in the cracks filled with $\mathrm{Cr}$-containing chlorite. It is worth noting the presence of $\mathrm{Cl}$ in this phase.

Unknown phase No. $2(\mathrm{Os}, \mathrm{Ir}, \mathrm{Ru}, \mathrm{As}, \mathrm{S}, \mathrm{O})$ is found in the millerite cracks in close association with chlorite and chrome-magnetite.

Unknown phase No. $3(\mathrm{Ru}, \mathrm{Ir}, \mathrm{Te}, \mathrm{Ni}, \mathrm{Ba}, \mathrm{S}, \mathrm{O})$ is found in chlorite in the intergrowth with laurite and irarsite. The $\mathrm{Ba}$ and $\mathrm{Te}$ impurities are unusual for the platinum phases of chromitites.

$\mathrm{Ni}, \mathrm{Fe}, \mathrm{Cu}$ sulphides and arsenides. The sulphides of base metals form a dispersed impregnation mainly in serpentine-chlorite aggregate. Heazlewoodite $\mathrm{Ni}_{3} \mathrm{~S}_{2}$ and millerite $\mathrm{NiS}$ are the predominant sulfide phases (Figure 5, Table 5). Heazlewoodite is often found in polyphase aggregates with secondary PGE minerals. It has a homogeneous composition and is identical in individual grains and in the intergrowth with platinum metal phases. 
Table 5. Chemical composition of $\mathrm{Ni}, \mathrm{Fe}$, and $\mathrm{Cu}$ sulfides and arsenides (wt. \%).

\begin{tabular}{|c|c|c|c|c|c|c|c|}
\hline $\begin{array}{c}\text { No. } \\
\text { Mineral }\end{array}$ & $\begin{array}{c}2 \mathrm{a}-12 \\
(\mathrm{Fe}, \mathrm{Ni})_{9} \mathrm{~S}_{8}\end{array}$ & $\begin{array}{r}6-12 \\
\mathrm{Cu}_{2} \mathrm{~S}\end{array}$ & $\begin{array}{c}6-13 \\
\mathrm{Ni}_{3} \mathrm{~S}_{2}\end{array}$ & $\begin{array}{l}3-13 \\
\mathrm{NiS}\end{array}$ & $\begin{array}{c}6-13 \\
\mathrm{Ni}_{3} \mathrm{~S}_{2}\end{array}$ & $\begin{array}{c}4-12 \\
\mathrm{Ni}_{3} \mathrm{~S}_{2}\end{array}$ & $\begin{array}{c}3-13 \\
\mathrm{Ni}_{3} \mathrm{As}_{2}\end{array}$ \\
\hline $\mathrm{Ni}$ & 38.9 & & 67.5 & 64.16 & 72.82 & 72.19 & 64.24 \\
\hline $\mathrm{Fe}$ & 25.58 & & & & & & \\
\hline $\mathrm{Cu}$ & & 64.89 & & & & & \\
\hline Co & 0.87 & & & & & & \\
\hline Os & & 4.34 & & & & & \\
\hline Ir & & 1.18 & & & & & \\
\hline $\mathrm{Ru}$ & & 8.01 & 5.29 & & & & \\
\hline $\mathrm{Rh}$ & & & 0.42 & & & & \\
\hline$S$ & 33.08 & 19.8 & 25.81 & 33.82 & 27.25 & 27.2 & \\
\hline As & & & 0.55 & & & & 36.01 \\
\hline $\mathrm{O}$ & & 1.06 & & & & & \\
\hline \multirow[t]{2}{*}{ Total } & 98.43 & 99.28 & 99.57 & 97.98 & 100.07 & 99.39 & 100.25 \\
\hline & $\begin{array}{l}\text { Incl. in } \\
\text { olivine }\end{array}$ & \multicolumn{3}{|c|}{$\begin{array}{c}\text { PGE bearing, intergrowth } \\
\text { with PGM }\end{array}$} & \multicolumn{3}{|c|}{ PGE-free, individual grains } \\
\hline
\end{tabular}

\section{Discussion}

\subsection{Chromitite Formation: Composition of Parental Melts}

Chromite bodies in ophiolites are formed due to the partial melting of rocks of the upper mantle. The interaction of the melt with mantle peridotites plays an important role in the formation of podiform chromitites. In the channel filled with molten mantle, the ascending olivine-chromite-cotectic melt mixes with the silica-enriched melt, formed through the harzburgite-melt reaction. The formation of surrounding dunites along the host harzburgites is the result of a combination of olivine precipitation from "older" magma and the destruction of orthopyroxene in harzburgite, interacting with the magma channel. Thin chromite schlieren and streaks can be formed by separating the chromite from the cotectic olivine-chromite melt [9,42-46].

In the $\mathrm{Pt} / \mathrm{Pt}^{*}-\mathrm{Pd} / \mathrm{Ir}$ diagram (Figure 11), dunites and chromitites are within the partial melting trend. The late metamorphic and hydrothermal processes, during which Pd enrichment occurred, probably cause the high Pd/Ir ratio in some Ulan-Sar'dag chromitites. In the OSMA diagram, most of the ore chrome spinels are in the olivine-spinel equilibrium field, and some of the chrome spinels are beyond this field. This can be explained by the distortion of the magmatic system closedness, changes in the compositions during the tectonic processes and metamorphism of chrome spinels. Chromitites of the USO were formed at the 28-35\% degree of partial melting (Figure 12). The data on the dunites, harzburgites, and chromitites of the northern and southern branches of the Ospa-Kitoy ophiolite are presented for comparison (Figure 12). The $\mathrm{Mg}^{\prime}(\mathrm{Ol})-\mathrm{Cr}^{\prime}(\mathrm{Sp})$ ratio in dunites and harzburgites corresponds to the $30-40 \%$ degree of partial melting; in ore chrome spinels from the northern branch, it corresponds to $30-40 \%$; in ore chrome spinels of the southern branch, it corresponds to $35 \%$. 


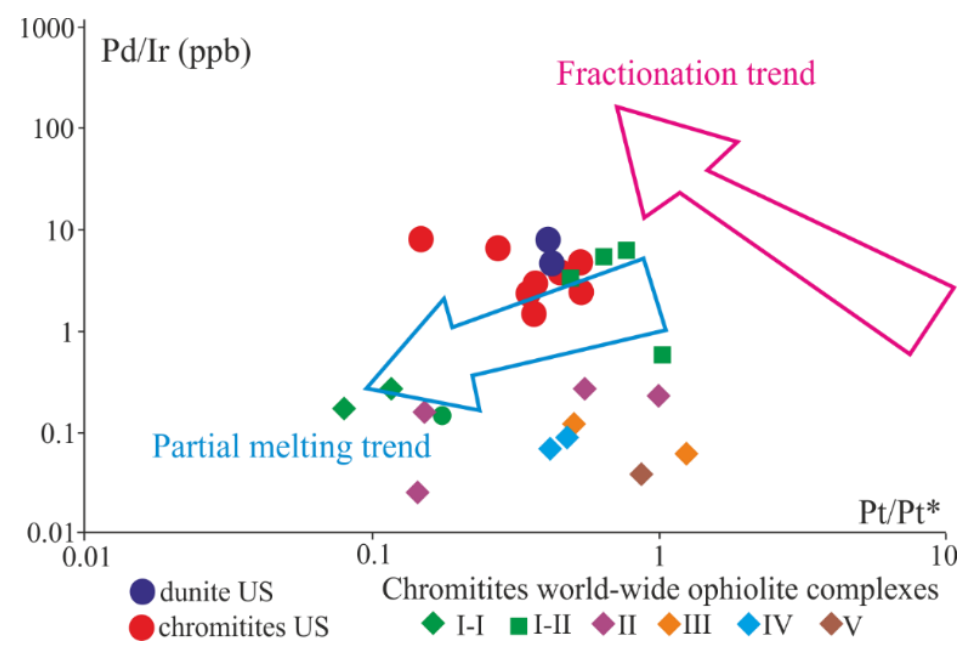

Figure 11. Plot of $\mathrm{Pd} / \mathrm{Ir}$ versus $\mathrm{Pt} / \mathrm{Pt}^{*}$ for mantle peridotite and chromitites of the USO. The $\mathrm{Pt}$ anomaly is calculated as follows: $\mathrm{Pt} /[\mathrm{Pt}]^{*}=(\mathrm{Pt} / 8.3) \times \sqrt{(\mathrm{Rh} / 1.6) \times(\mathrm{Pd} / 4.4)}$ [8]. US-Ulan-Sar'dag ophiolite; ophiolite complexes from around the world: I-Wadi Al Hwanet ophiolite, Saudi Arabia [47]; II-Oman ophiolite, Semail [48]; III—Veria ophiolite, Greece [49]; IV—Shetland Ophiolite Complex, Scotland [50]; V-Ray-Iz ophiolite, Russia [51].

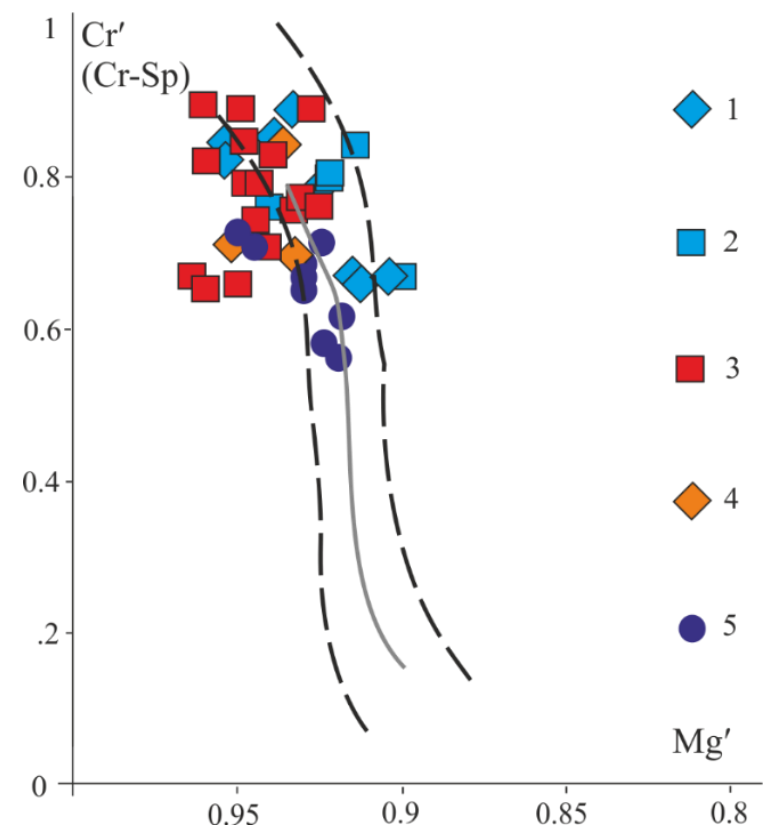

Figure 12. OSMA (olivine-spinel mantle array) is a spinel peridotite restite trend [52]. The chrome spinels are from: 1-4-the Ospa-Kitoy ophiolite: 1—dunites; 2-harzburgites; the chromitites are from: 3-the north-branch Ospa-Kitoy, 4-south-branch Ospa-Kitoy; 5-Ulan-Sar'dag ophiolite. $\mathrm{Mg}^{\prime}-\mathrm{Mg} /(\mathrm{Mg}$ $+\mathrm{Fe})$ in olivine; $\mathrm{Cr}-\mathrm{Cr} /\left(\mathrm{Cr}+\mathrm{Al}+\mathrm{Fe}^{3+}\right)$ in chrome spinel.

The composition of the chrome spinels of the USO varies significantly, which may reflect the interaction of mantle peridotites with the melts of various compositions. The joint presence of high-Cr' and high- $\mathrm{Al}^{\prime}$ chrome spinels is common in many ophiolite belts, but as a rule, chrome spinels with different compositions are found in different ophiolite nappes [7,9,52-59]. Their joint occurrence in one ophiolite nappe is less common; in this case, the ophiolite nappe, as a rule, contains peridotites depleted to different degrees [45,60-63]. The composition of chrome spinels of podiform chromitites that includes, as the main components, $\mathrm{FeO}, \mathrm{MgO}, \mathrm{Al}_{2} \mathrm{O}_{3}$, and $\mathrm{TiO}_{2}$ is a function of the composition of the parental melts $[9,15,16,18,21,64]$. We have calculated the contents of the $\mathrm{Al}_{2} \mathrm{O}_{3}, \mathrm{TiO}_{2}$ and $\mathrm{FeO}-\mathrm{MgO}$ 
ratios in the parental melts, which were in equilibrium with the podiform chromitites (Table 6), according to Equations (1)-(3) [15]. Table 6 shows, for comparison, the values of these parameters for the chrome spinels of ophiolites from around the world.

$$
\begin{gathered}
\mathrm{Al}_{2} \mathrm{O}_{3 \mathrm{Sp}}(\text { wt. } \%)=0.035 \times\left(\mathrm{Al}_{2} \mathrm{O}_{3}\right)_{\text {melt }}{ }^{2.42}, \\
\mathrm{TiO}_{2 \text { (melt) }}(\text { wt. } \%)=\mathrm{TiO}_{2 \mathrm{Sp}}{ }^{0.82524} \times e^{0.20203} \\
\operatorname{Ln}(\mathrm{FeO} / \mathrm{MgO})_{S p}=0.47-1.07 \times \mathrm{Al}^{\prime}{ }_{\text {Sp }}+0.64 \times \mathrm{Fe}^{3+\prime}+\operatorname{Ln}(\mathrm{FeO} / \mathrm{MgO})_{\text {melt }}, \text { where } \mathrm{Al}^{\prime} \text { Sp }=\mathrm{Al} /(\mathrm{Al} \\
\left.+\mathrm{Cr}+\mathrm{Fe}^{3+}\right) \text { and } \mathrm{Fe}^{3+\prime}{ }_{\mathrm{Sp}}=\mathrm{Fe}^{3+} /\left(\mathrm{Al}+\mathrm{Cr}+\mathrm{Fe}^{3+}\right)
\end{gathered}
$$

The chemical composition of the chrome spinels I group (Crsp I) and the composition of the parental melt are similar in these parameters for medium-aluminous chrome spinels of the Ospa-Kitoy

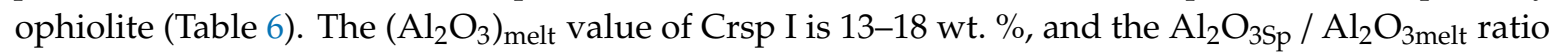
corresponds to the spreading trend and abyssal peridotites (Figure 13a). Despite the low $\mathrm{TiO}_{2}$ content, Crsp I has the $\mathrm{TiO}_{2 \mathrm{Sp}} / \mathrm{TiO}_{2 \text { melt }}$ trend, which is calculated for spinels from the MORB-type peridotites (Figure 13b).

The chemical composition of the chrome spinels II group (Crsp II) and the composition of the parental melt are similar in these parameters for the low- $\mathrm{Al}^{\prime}$ chrome spinels of the Ospa-Kitoy ophiolite (Table 6). The $\left(\mathrm{Al}_{2} \mathrm{O}_{3}\right)_{\text {melt }}$ values for the chrome spinels of groups II and III are 10-12 and $10-13$ (wt. \%), and the $(\mathrm{FeO} / \mathrm{MgO})$ melt ratio is $0.4-0.85$ and $0.7-1$, respectively. The values of the $\mathrm{Al}_{2} \mathrm{O}_{3 \mathrm{Sp}} / \mathrm{Al}_{2} \mathrm{O}_{3 \text { melt }}$ ratios in chrome spinels II and III correspond to the trend of the chrome spinels from the island-arc boninites and chromitites of the Ural-Alaska complexes (Figure 13c). The $\left(\mathrm{TiO}_{2}\right)_{\text {melt }}$ values for the chrome spinels I, II, and III groups overlap because of the low $\mathrm{TiO}_{2}$ content (0-0.2 wt. \%). In general, the values of $\left(\mathrm{Al}_{2} \mathrm{O}_{3}\right)_{\text {melt }} /(\mathrm{FeO} / \mathrm{MgO})$ are similar to the high-Cr' chrome spinels from the Troodos and Zetford Mine ophiolites (Figure 13d), which were formed in a suprasubduction setting. In the discrimination relationship diagrams, the $\left[\mathrm{Al}_{2} \mathrm{O}_{3} / \mathrm{Fe}^{2+} / \mathrm{Fe}^{3+}\right],\left[\mathrm{Mg}^{\prime} / \mathrm{Cr}^{\prime}\right]$, and $\left[\mathrm{Al}_{2} \mathrm{O}_{3} / \mathrm{TiO}_{2}\right]$ (Figure $14 \mathrm{a}-\mathrm{c}$ ) of the chrome spinels I group are in the field of the MORB-type peridotites. Chromitites were formed during the interaction of harzburgites with primitive MORB-like melts at deep levels of the upper mantle. Through the interaction of MORB-type melts, which are in equilibrium with abyssal dunites [65,66], precipitation of chrome spinels with $\mathrm{Cr}^{\prime} \quad 0.4-0.6$, as a product of the melt-peridotite reaction, is possible [43,67]. Among the volcanic rocks of the USO, metabasalts, with enriched mid-ocean ridge basalt (E-MORB) geochemical characteristics, are available [68].

The chrome spinels II group is localized in the boninite field. The $\mathrm{TiO}_{2}$ and $\mathrm{Al}_{2} \mathrm{O}_{3}$ content corresponds to the chrome spinels of the suprasubduction peridotites and overlaps with the chrome spinels from the New Caledonia island arc (Figure 14c). The chrome spinels II are formed during the reaction of the peridotites with the island-arc boninite melt in the subduction zone. The chrome spinels III group lies on the boundary of the boninite fields and magmatic complexes of the Ural-Alaskan type. Three mechanisms can be suggested for the formation of the third type of chrome spinels. The first is the interaction with high-iron low-titanium melts [81]. The second mechanism is through plastic deformations under mantle or crust-mantle conditions (low $\mathrm{fO}_{2}$, Table 1), because of the reactions of the $\mathrm{Mg}-\mathrm{Fe}$ exchange with olivine. High-iron chrome spinels are found in the structural types of chromite, including chromitites with deformation structures. When compared with chrome spinels of the Alaskan type chromitites, the chrome spinels III group from the chromitites of the USO have low $\mathrm{TiO}_{2}$ contents, high $\mathrm{Cr}_{2} \mathrm{O}_{3}$ contents and low (mantle) $f \mathrm{O}_{2}$ values (Table 1 ). Variations in $\mathrm{TiO}_{2}$ contents, from 0 to $0.22 \mathrm{wt}$ \%, may indicate a reaction with $\mathrm{TiO}_{2}$-containing melts [82]. The third mechanism is through the partial melting of the fluid-metasomatized mantle during the interaction of andesitic melts with rocks of an overlying mantle wedge [71,83,84]. 
Table 6. Calculated parental melt composition of chrome spinels.

\begin{tabular}{|c|c|c|c|c|c|c|}
\hline & Cr-Spinels & $\mathbf{A l}^{\prime}$ & $\mathrm{Cr}^{\prime}$ & $\mathbf{M g}^{\prime}$ & Parental Melt (wt. \%) & References \\
\hline 1 & I group & $24-60$ & $36-74$ & $45-74$ & $\begin{array}{c}\mathrm{Al}_{2} \mathrm{O}_{3}, 13-18 ; \mathrm{TiO}_{2}, 0-0.14 \\
\mathrm{FeO} / \mathrm{MgO}, 0.2-0.7\end{array}$ & In this article \\
\hline 2 & II group & $14-23$ & $74-81$ & $32-48$ & $\begin{array}{c}\mathrm{Al}_{2} \mathrm{O}_{3}, 10-12 ; \mathrm{TiO}_{2}, 0-0.35 \\
\mathrm{FeO} / \mathrm{MgO}, 0.4-0.85\end{array}$ & In this article \\
\hline 3 & III group & $13-27$ & $68-81$ & $28-35$ & $\begin{array}{c}\mathrm{Al}_{2} \mathrm{O}_{3}, 10-13 ; \mathrm{TiO}_{2} \\
0.08-0.13 \\
\mathrm{FeO} / \mathrm{MgO}, 0.7-1\end{array}$ & In this article \\
\hline 4 & $\begin{array}{l}\text { Ospa-Kitoy } \\
\text { medium } \mathrm{Al}^{\prime}\end{array}$ & $24-41$ & $59-75$ & $43-70$ & $\begin{array}{c}\mathrm{Al}_{2} \mathrm{O}_{3}, 12-14 ; \mathrm{TiO}_{2} \\
0.01-0.44 \\
\mathrm{FeO} / \mathrm{MgO}, 0.5-1.1\end{array}$ & [38] \\
\hline 5 & $\begin{array}{l}\text { Ospa-Kitoy low } \\
\mathrm{Al}^{\prime}\end{array}$ & $9-21$ & $77-90$ & $23-59$ & $\begin{array}{c}\mathrm{Al}_{2} \mathrm{O}_{3}, 8-11 ; \mathrm{TiO}_{2} \\
0.01-0.48 \\
\mathrm{FeO} / \mathrm{MgO}, 0.5-2.4\end{array}$ & [38] \\
\hline 6 & MORB & $35-64$ & $29-57$ & $57-59$ & $\begin{array}{c}\mathrm{Al}_{2} \mathrm{O}_{3} 13-18 ; \mathrm{TiO}_{2}, 0.3-1.7 \\
\mathrm{FeO} / \mathrm{MgO}, 0.5-0.7\end{array}$ & {$[18,69] ;$} \\
\hline 7 & BAB & 61 & 34 & 75 & $\begin{array}{c}\mathrm{Al}_{2} \mathrm{O}_{3}, 17.6 ; \mathrm{TiO}_{2}, 0.4 \\
\mathrm{FeO} / \mathrm{MgO}, 0.4\end{array}$ & [18] \\
\hline 8 & OIB & 28 & 61 & 57 & $\begin{array}{l}\mathrm{Al}_{2} \mathrm{O}_{3}, 12 ; \mathrm{TiO}_{2}, 1.6 \\
\mathrm{FeO} / \mathrm{MgO}, 0.6\end{array}$ & [18] \\
\hline 9 & IAB & $15-29$ & $61-68$ & $58-69$ & $\begin{array}{c}\mathrm{Al}_{2} \mathrm{O}_{3}, 9-12 ; \mathrm{TiO}_{2}, 0.4-0.7 \\
\mathrm{FeO} / \mathrm{MgO}, 0.3-0.5\end{array}$ & [18] \\
\hline 10 & IABon, IAT & 5-19 & $74-89$ & $58-75$ & $\begin{array}{c}\mathrm{Al}_{2} \mathrm{O}_{3}, 6-10 ; \mathrm{TiO}_{2} \\
0.08-0.4 \\
\mathrm{FeO} / \mathrm{MgO}, 0.2-0.4\end{array}$ & [18] \\
\hline 11 & LIP & $13-35$ & $52-72$ & $35-61$ & $\begin{array}{c}\mathrm{Al}_{2} \mathrm{O}_{3}, 8-13 ; \mathrm{TiO}_{2}, 0.2-0.5 \\
\mathrm{FeO} / \mathrm{MgO}, 0.4-1.2\end{array}$ & [18] \\
\hline 12 & $\begin{array}{c}\text { Abissal } \\
\text { peridotite }\end{array}$ & $45-77$ & $20-50$ & $64-77$ & $\begin{array}{c}\mathrm{Al}_{2} \mathrm{O}_{3}, 15-19 ; \mathrm{TiO}_{2} \\
0.08-0.1 \\
\mathrm{FeO} / \mathrm{MgO}, 0.4-0.5\end{array}$ & {$[70]$} \\
\hline 13 & $\begin{array}{c}\text { Chromite in } \\
\text { ophiolite mantle }\end{array}$ & $40-51$ & $44-52$ & $63-74$ & $\begin{array}{c}\mathrm{Al}_{2} \mathrm{O}_{3}, 14-16 ; \mathrm{TiO}_{2} \\
0.2-0.5 \\
\mathrm{FeO} / \mathrm{MgO}, 0.3-0.6\end{array}$ & [3] \\
\hline 14 & $\begin{array}{c}\text { Chromite in } \\
\text { ophiolite mantle }\end{array}$ & $21-28$ & $67-74$ & $56-68$ & $\begin{array}{c}\mathrm{Al}_{2} \mathrm{O}_{3}, 10-12 ; \mathrm{TiO}_{2} \\
0.1-0.3 \\
\mathrm{FeO} / \mathrm{MgO}, 0.54-0.6\end{array}$ & {$[3,48]$} \\
\hline 15 & $\begin{array}{l}\text { Chromite in } \\
\text { Alaskan type }\end{array}$ & $11-14$ & $62-70$ & $45-56$ & $\begin{array}{c}\mathrm{Al}_{2} \mathrm{O}_{3}, 8-9 ; \mathrm{TiO}_{2}, 0.6-0.9 \\
\mathrm{FeO} / \mathrm{MgO}, 0.4-0.5\end{array}$ & [71] \\
\hline
\end{tabular}

\subsection{Spinel and Olivine Geothermometers and Olivine-Spinel Oxybarometers}

Several processes condition the composition of chrome spinels: partial melting, cooling of mantle peridotites and plastic deformations in the upper mantle. Many researchers have shown that, during ultramafite cooling, regardless of their formation (mantle or cumulative), ( $\mathrm{Mg} \leftrightarrow \mathrm{Fe}^{2+}$ ) exchange reactions take place between coexisting olivines and chrome spinels, as a result of which the coefficient of these elements' distribution increases in favor of chrome spinels, and consequently, the calculated temperatures of the olivine-spinel equilibrium decrease [85-87]. During plastic deformations, exchange processes and rebalancing between olivine and chrome spinels also occur, and schlieren and lenticular segregations of chromitites transform into massive chromite bodies (Figure $4 \mathrm{c}-\mathrm{f}$ ). Based on this, it is assumed that the obtained values for the temperature, pressure and oxygen fugacity correspond not to the formation of ultramafites and chromitites, but to the stages of the formation and transformation 
of these bodies: the tectonic flow of the upper mantle rocks, the effect of metasomatizing fluids and other processes.
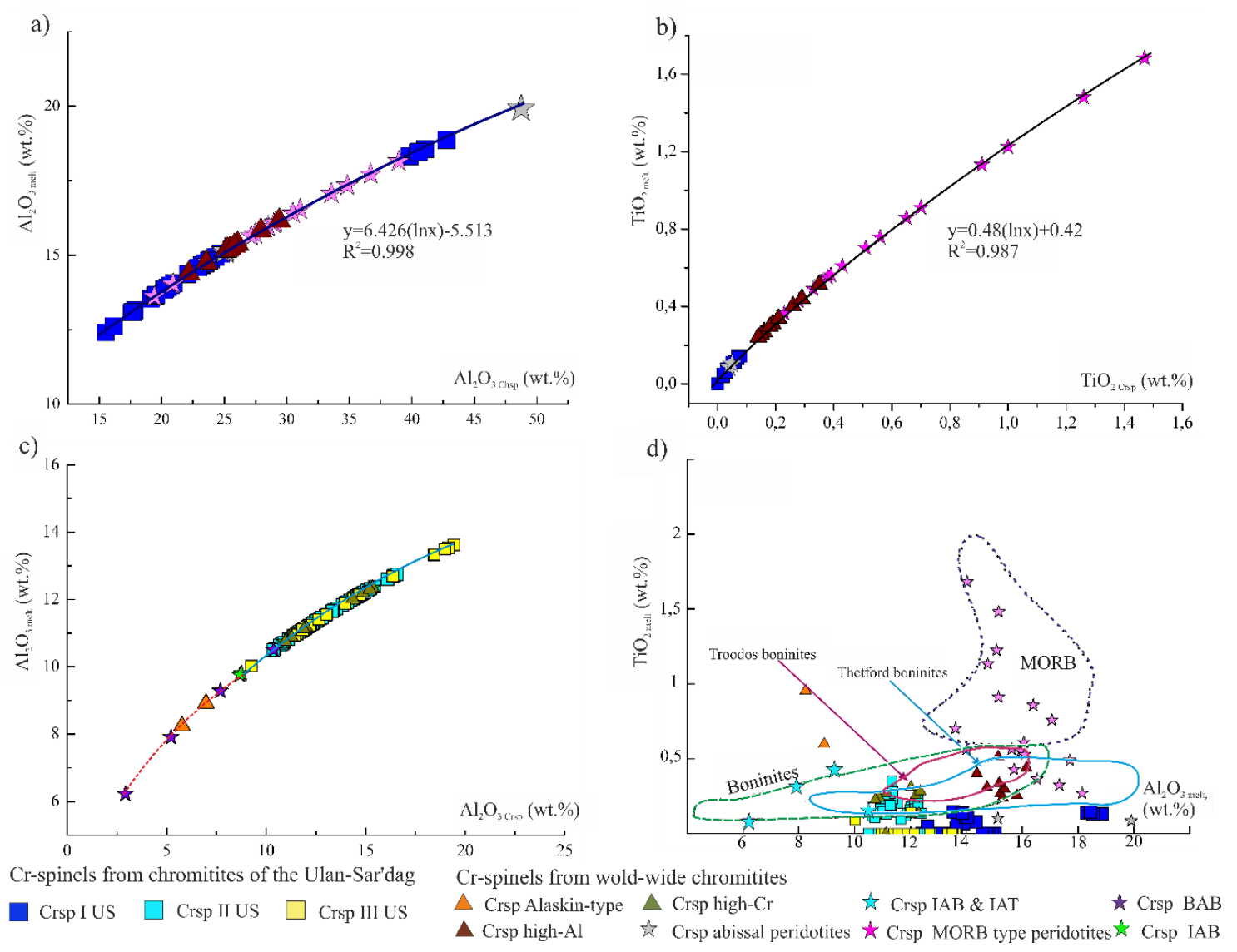

Figure 13. Plots of relations: (a) $\mathrm{Al}_{2} \mathrm{O}_{3}$-Crsp $-\mathrm{Al}_{2} \mathrm{O}_{3}$ melt; (b) $\mathrm{TiO}_{2}$ Crsp $-\mathrm{TiO}_{2}$ melt; (c) $\mathrm{Al}_{2} \mathrm{O}_{3}$ Crsp $-\mathrm{Al}_{2} \mathrm{O}_{3}$ melt; (d) calculated abundance of $\mathrm{Al}_{2} \mathrm{O}_{3}-\mathrm{TiO}_{2}$ in melt, as in the equilibrium with the $\mathrm{Cr}$ spinels from the chromitites of the USO and the chrome spinels of chromitites from all over the world. The fields for the chrome spinels of boninites [72-74], Troodos boninites [75,76], Thetford boninites [77] and MORB [78-80] are shown for comparison.

We have calculated and estimated the P-T parameters with the help of an olivine-spinel (Ol-Sp) geothermometer, provided in [88]. The oxygen fugacity was determined using an Ol-Sp oxybarometer, provided in [89], in accordance with oxybarometers [90,91]. For the chrome spinels I group (high $\left.\mathrm{Al}^{\prime}\right)$, the calculated temperatures of the Ol-Sp equilibrium are $T_{\mathrm{Ol}-\mathrm{Sp}}=1020-920{ }^{\circ} \mathrm{C}$, and $f \mathrm{O}_{2}=(-0.7)-(-1.5)$ (Table 1); for the chrome spinels II group (medium-, low- $\mathrm{Al}^{\prime}$ ), the calculated temperatures are $T_{\text {Ol-Sp }}=891-1003{ }^{\circ} \mathrm{C}$, and $f \mathrm{O}_{2}=(-1.1)-(-4.4)$; for the chrome spinels III group, these values are $T_{\mathrm{Ol}-\mathrm{Sp}}=846-738{ }^{\circ} \mathrm{C}$, and $\mathrm{fO}_{2}=(-1.49)-(-3.01)$. For the chrome spinels containing inclusions of laurite-erlichmanite, $T_{\mathrm{Ol}-\mathrm{Sp}}=916-938^{\circ} \mathrm{C}$, and $f \mathrm{O}_{2}=-2.4$. For the chrome spinels with the olivine inclusion, $\mathrm{T}_{\mathrm{Ol}-\mathrm{Sp}}=991.6^{\circ} \mathrm{C}$, and $\mathrm{fO}_{2}=(-1.3)$. The temperature values overlap, but for the chrome spinels II group, higher temperatures are noted. The values of $f \mathrm{O}_{2}$ are discrete. It is assumed that a more reducing environment and higher solid-phase reaction temperatures are required for the formation of the chrome spinels II group, in comparison with the chrome spinels groups III and I. The content of impurities $\left(\mathrm{Al}_{2} \mathrm{O}_{3}\right)$ in olivine was used as an alternative geothermometer. For our objects, this method was limited by the small amount of preserved olivine. We were interested in the chromitites containing PGE- and PGE-free mineralization. Using the geothermometer of De Hoog and Gall for the Al content in olivine [25], the temperature was estimated by Equation (4). For the 
chromitites containing PGM, the temperature, according to the olivine thermometer, was $893-1332{ }^{\circ} \mathrm{C}$, and for the PGM-free chromitites, it was $1073-1225^{\circ} \mathrm{C}$ (Table 1).

$$
T_{\mathrm{ol}}(\mathrm{C})=1087 /\left(7.46-\ln \mathrm{Al}_{\mathrm{ppm}}\right)-273
$$

An assessment of the temperature using an olivine thermometer and inclusions of primary high-temperature (Os-Ir- $\mathrm{Ru}$ )-I alloys gives the values of $1200-1300{ }^{\circ} \mathrm{C}$, which is more consistent with the expected temperatures of the chrome spinel formation from the melt.
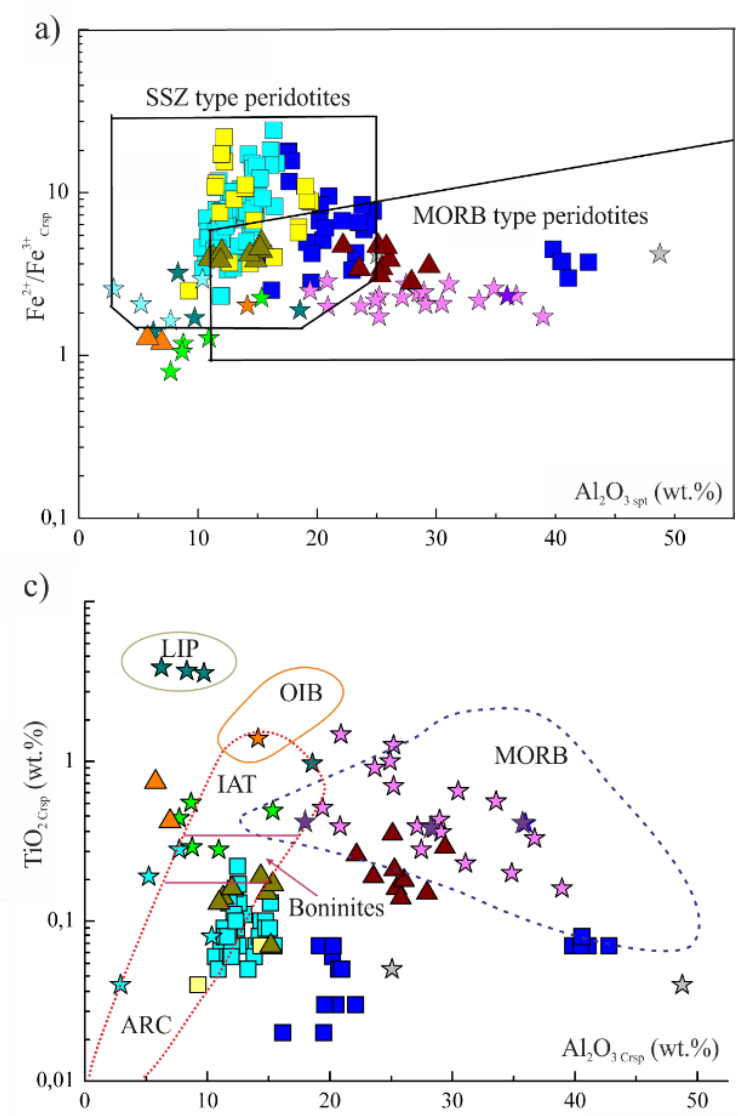

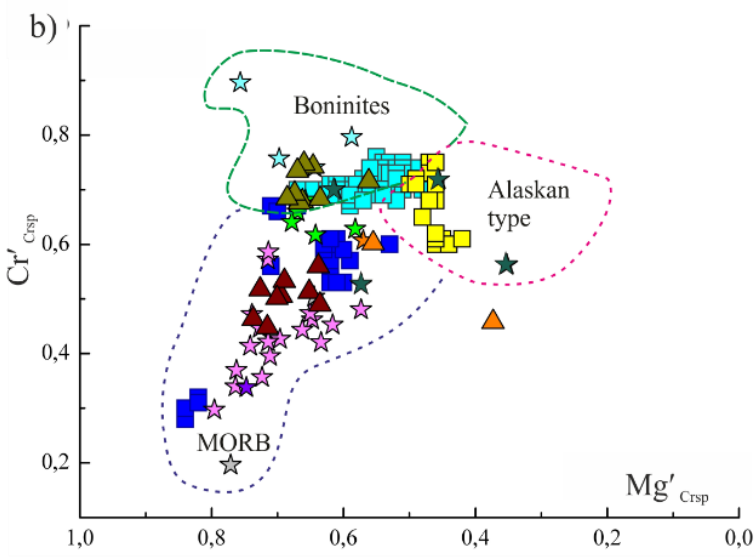

Cr-spinels from chromitites of the Ulan-Sar'dag

Crsp I US

Crsp II US

$\square$ Crsp III US

Cr-spinels from wold-wide chromitites

$\triangle$ Crsp Alaskin-type

- Crsp high-Al

A Crsp high-Cr

Crsp abissal peridotites

Crsp IAB \& IAT

$\star$ Crsp MORB type peridotites

$\star$ Crsp BAB

须 Crsp IAB

$\star$ Crsp LIP

Figure 14. Tectonic discrimination diagrams: (a) $\mathrm{Al}_{2} \mathrm{O}_{3}-\mathrm{Fe}^{2+} / \mathrm{Fe}^{3+}$; (b) $\mathrm{Mg}_{\text {sp }}^{\prime}-\mathrm{Cr}_{\text {sp }}^{\prime}$; (c) $\mathrm{Al}_{2} \mathrm{O}_{3}-\mathrm{TiO}_{2}$ from the chromitites of the USO and chrome spinels of chromitites from all over the world. The chrome spinels' composition fields for peridotites from different geodynamic settings are drawn from [18].

\subsection{Distribution of PGE in Mantle Peridotites and Chromitites}

The form of PGE distribution in the mantle peridotites and chromitites of ophiolites reflects the mantle conditions of chromitite formation and PGE mineralization. In the process of partially melting the mantle source, the PGEs fractionate. The melt is enriched in $\mathrm{Rh}, \mathrm{Pt}$, and Pd (PPGE), since PPGE is incompatible with Os, Ir, and $\mathrm{Ru}$ (IPGE). The mantle restite will be enriched in IPGE $[17,92,93]$. This process is confirmed by the form of PGE distribution in the Ulan-Sar'dag peridotites (Figure 15a,b), for which $\sum$ IPGE $>\sum$ PPGE. 

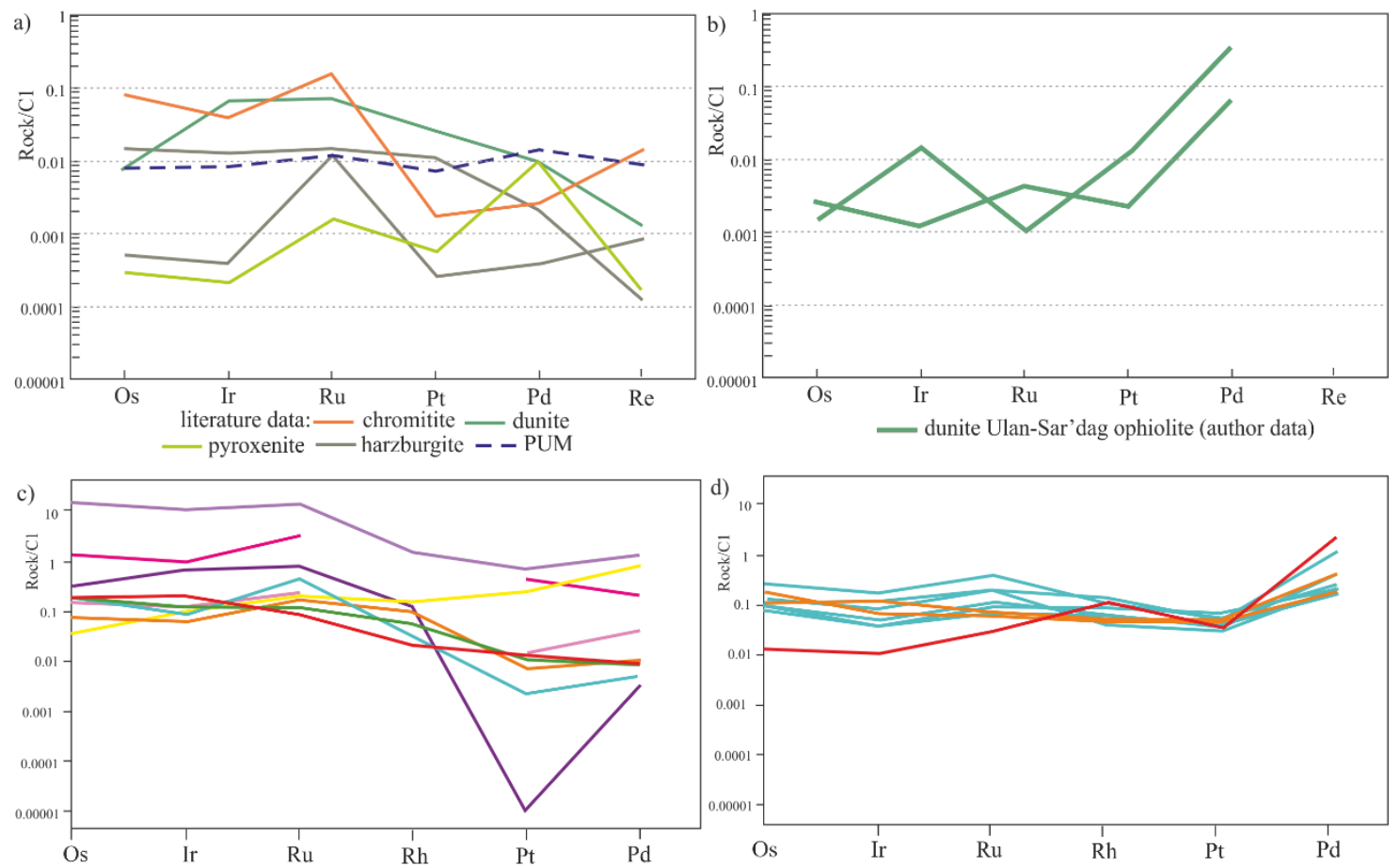

literature data world-wide ophiolite complexes (chromitites):

- Wadi Al Hwanet ophiolite-1 - Oman ophiolite - Shetland ophiolite-1

Wadi Al Hwanet ophiolite-2 — Veria ophiolite-1 Shetland ophiolite-2

- Mongolia ophiolite $\quad$ Veria ophiolite-2 2 Ray-Iz ophiolite

- I-types of PGE distribution (positive slope from Ir to Ru)

II-types of PGE distribution (negative slope from Os to Pt)

III-types of PGE distribution (positive slope from Pt to Pd)

Figure 15. Diagrams: (a) PGE distribution in the Ulan-Sardag peridotite literature data [94]; (b) PGE distribution in the Ulan-Sar'dag peridotite author data; (c) PGE pattern of chromitites of ophiolite complexes from all over the world: The Wadi Al Hwanet ophiolite, Saudi Arabia [47]; Oman ophiolite, Semail [48]; Veria ophiolite, Greece [49]; Shetland Ophiolite Complex, Scotland [50]; Ray-Iz ophiolite, Russia [51]; Mongolian ophiolite [95]; 1—chromitites are enriched in Os-Ir-Ru; 2—chromitites are enriched in Pt-Pd; (d) PGE patterns in the Ulan-Sar'dag chromitites.

In the case of a low degree of partial melting, there are no obvious differences between the PPGE and IPGE contents, and the PGE distribution is flat. At a high degree of partial melting, PPGE is depleted in restite mantle rocks, relative to IPGE, and the total PGE contents become lower. In this case, the distributions have a negative slope. The PGE distribution in the mantle peridotite of Ulan-Sar'dag demonstrates: (1) a positive Ru and Pd picks; (2) a flat type of distribution, with a negative slope towards $\mathrm{Pd}$; (3) a positive slope of $\mathrm{Ir}, \mathrm{Rh}$, and $\mathrm{Pt}$ and a negative slope of $\mathrm{Ru}$ (Figure 15b). Podiform chromitites are characterized by a fractionated form of PGE distribution (Figure 15c), which indicates a high degree of partial melting (about $20 \%-24 \%$ ) of the mantle source. Three types of PGE distribution are observed in Ulan-Sar'dag chromitites (Figure 15d): (1) a negative slope from Os to Ir and Ru to Pt and a positive slope from $\mathrm{Ir}$ to $\mathrm{Ru}$ and $\mathrm{Pt}$ to $\mathrm{Pd}$; (2) a negative slope of the distribution curve from Os to $\mathrm{Pt}$ and a positive slope from $\mathrm{Pt}$ to $\mathrm{Pd}$; (3) low contents of $\mathrm{Os}$, Ir and $\mathrm{Ru}$ and an enrichment in $\mathrm{Rh}$ (Pd is uncharacteristic of chromitites). Chondrite-normalized PGE relations in chromitites of the USO are similar to those of chromitites of ophiolites (Figure 15c,d) formed in a suprasubduction environment from all over the world $[7,11,57,63,96-98]$. The pronounced positive Ru anomaly is due to the predominant laurite phase in the chromitites of the USO. It is known that Ru has a maximum affinity with S, and the predominance of IPGE sulfides, in turn, indicates a high fugacity of sulfur in the melt, in contrast to the parental melts for chromitites of the northern and southern branches of the Ospa-Kitoy ophiolite (Figure 16a-c). 
a)

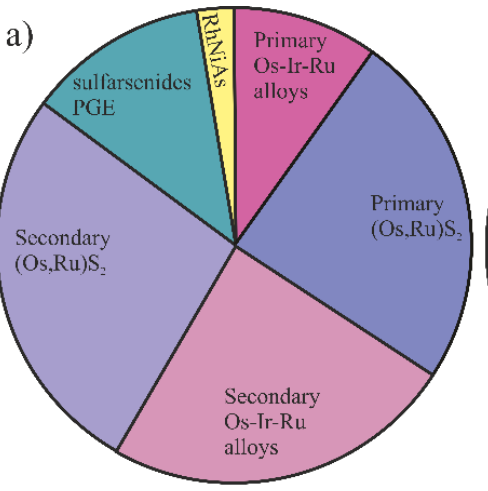

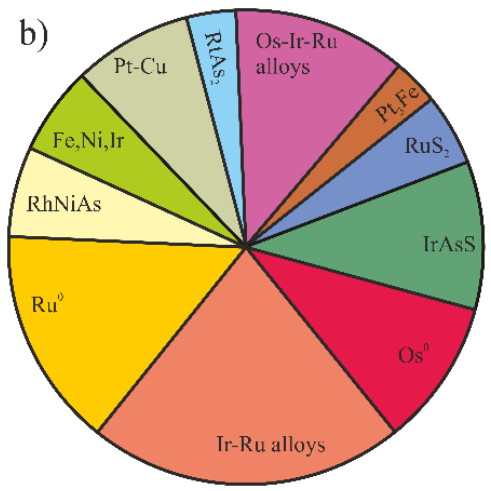

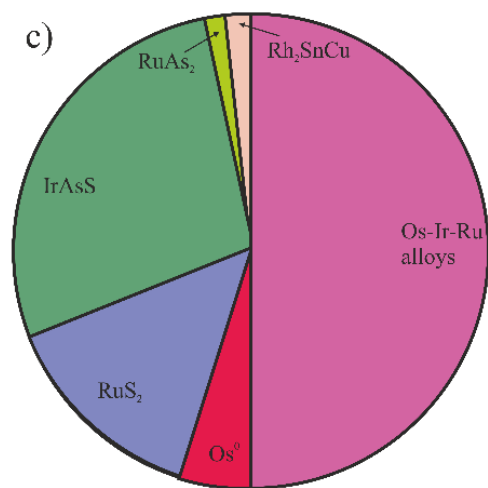

Figure 16. PGE assemblage (a) Ulan-Sar'dag chromitites; (b) the northern branch of the SEPES ophiolite; (c) the southern branch of the SEPES ophiolite [36].

The experimental data show that Os, Ir, and Ru are concentrated by trapping submicroscopic clusters of these elements in the metallic state during chromite crystallization [99-101]. Tsoupas [49] believes that an IPGE enrichment in chromitites can be associated with post-magmatic processes during a long period of deformations, beginning from plastic deformations in the asthenospheric mantle and ending with brittle deformations in the crust. This is confirmed by wide variations in the contents of IPGE, PPGE and the IPGE/PPGE ratio from 0.03 to 2.15 (Table 3) in the studied chromitites. Negative $\mathrm{Pt}$ anomalies in chromitites are closely related to the unique properties of $\mathrm{Pt}$ itself. The distribution coefficients of the alloy/sulfide liquid at $1000{ }^{\circ} \mathrm{C}$ are $1-2$ for $\mathrm{Pd}$ and more than 1000 for Pt. Thus, the distribution coefficient of the alloy/sulfide melt for Pt is 1000 times greater than it is for Pd [102]. This is confirmed by the distribution diagrams, where a Pt negative anomaly is clearly visible (Figure 15c,d). An extreme Pd enrichment in one of the chromitites is most likely associated with late magmatic processes and exposure to the reduced fluid. Chrome spinels has high $\mathrm{FeO}$ contents and low $f \mathrm{O}_{2}$ values. There are no Pd phases in this chromite. We believe that PGM is concentrated in recrystallized dunite, which requires further study. Detailed studies on the metaperidotites, metagabbros, and metavolcanogenic sedimentary rocks of the USO showed that some rocks have signs of significant exposure to a high-temperature fluid phase, which leads to rock metasomatism $[68,103]$.

\subsection{Sequence of the Formation and Transformation of the Platinum-Group Mineral Assemblage}

Based on the chemical and textural features of PGM and associations with the magmatic and hydrothermal minerals of chromitites, several stages of PGE mineralization were distinguished (Figure 17).

\section{- I-Magmatic Stage}

At the magmatic stage, under the upper mantle conditions, euhedral-subhedral high-temperature Os-Ir-Ru I alloys and laurite I are formed (Figures 8 and 9a-d), which are captured by chromite grains $[5,11,22,104-106]$. The high osmium content in the primary (Os-Ir-Ru) I alloys is caused by an early crystallization of laurite-erlichmanite (Figure 9c). According to the experimental data, laurite without an Os impurity crystallizes from the melt at a high temperature $\left(T=1200-1300{ }^{\circ} \mathrm{C}\right)$, $\mathrm{P}=5-10 \mathrm{kbar}$ and low log sulfur fugacity $\left(f \mathrm{~S}_{2}\right)$, from $(-0.39)$ to 0.07 [24,106-109]. A decrease in temperature and increase in $f S_{2}$ leads to a replacement of Ru by Os, and as a result, laurite rich in Os is formed. The predominance of laurite-erlichmanite over solid (Os-Ir-Ru) solutions in the chromitites of the USO is a distinctive feature, in comparison with the PGE mineralization of the northern and southern branches of the Ospa-Kitoy ophiolite (Figure 16a-c). In combination with the high and medium $\mathrm{Al}^{\prime}$ chrome spinels, this indicates the formation of chromitites and PGE mineralization of the USO because of the interaction between the initially S-saturated tholeiite magma and depleted 
harzburgites. Sulfarsenides and arsenides of $\mathrm{Ru}$ and $\mathrm{Ir}$ are formed from the residual fluid phase at the late magmatic stage (Figure $10 \mathrm{~g}, \mathrm{~h}$ ). With magmatic system cooling, volatile components, such as $\mathrm{S}$ and As, accumulate with the formation of the residual fluid phase. There is a partial replacement of laurite by irarsite with the formation of laurite II.

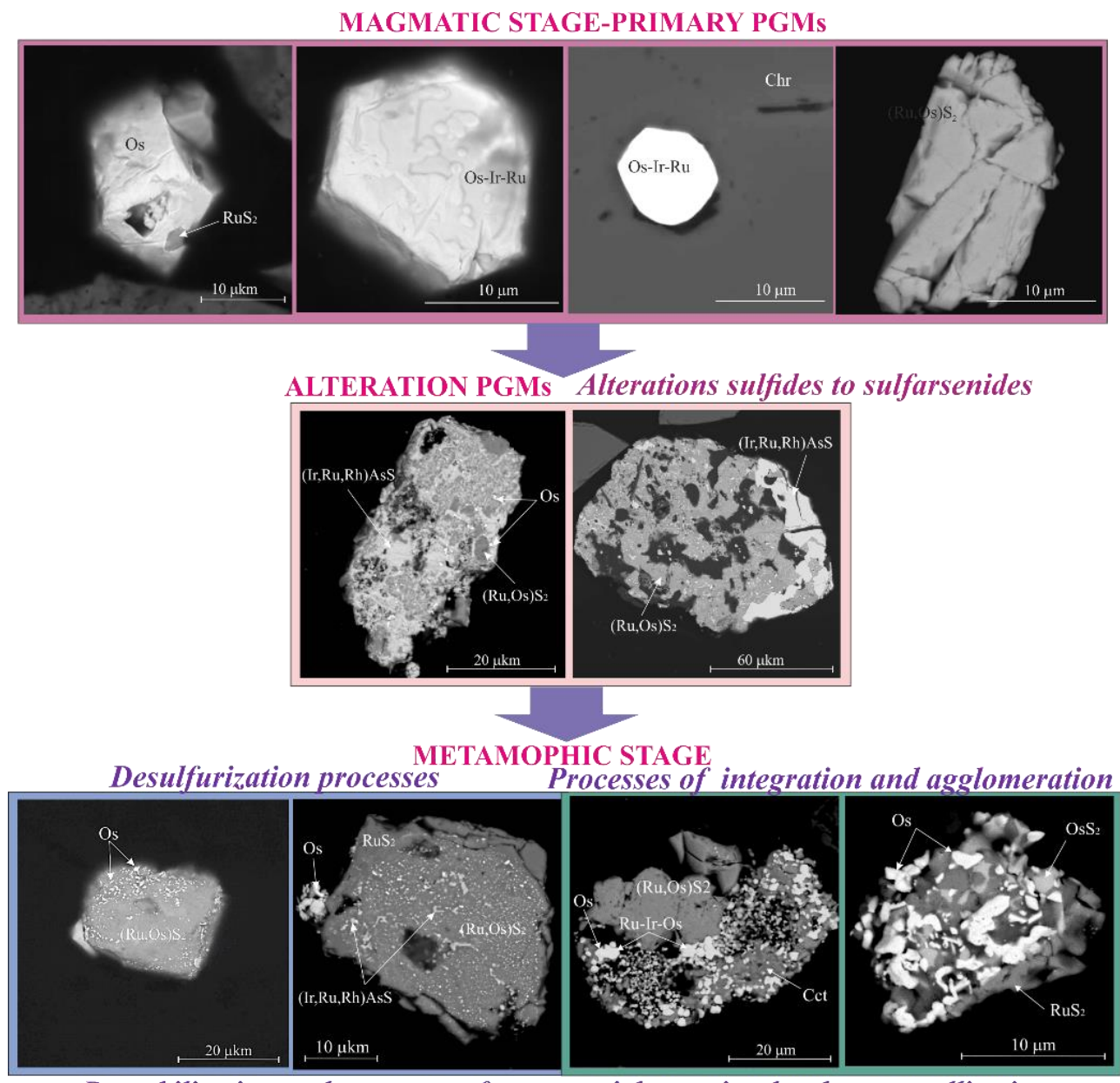

Remobilization, enlargement of nanoparticle to microlevel, recrystallization
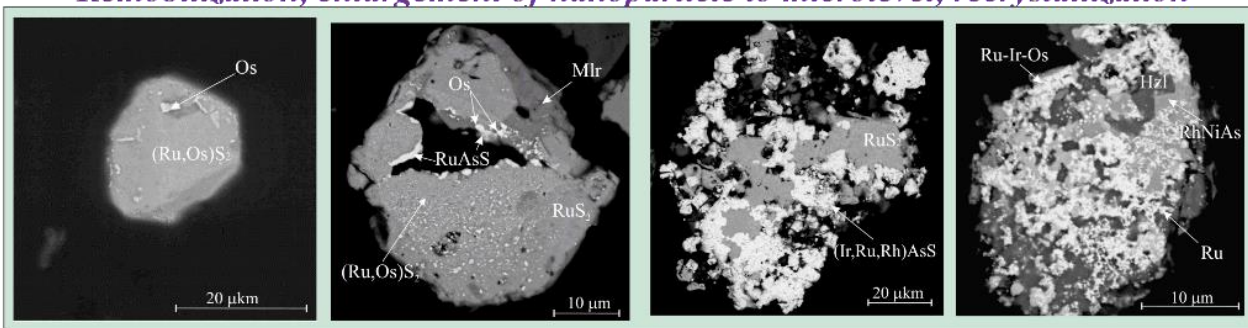

Figure 17. Scheme of the alteration and transformation of platinum-group minerals.

- II-Stage of Serpentinization and Exposure of Fluid

The PGMs in chromitites demonstrate signs of PGE remobilization (Figure 10a-d). The most intense changes of PGMs occur at the stage of the serpentinization of ultramafites. A fluid-rock interaction occurs with the participation of reduced gases $\left(\mathrm{H}_{2}, \mathrm{CH}_{4}\right)$ and the $\mathrm{H}_{2} \mathrm{O}$ of mantle origin. Dehydrating rocks of the subducting slab, as well as mantle-reduced fluids penetrating along the fault zones in tectonically weakened sectors, serve as the fluid source. At this stage, the following platinum-metal phases are formed: native Os and $\mathrm{Ru}$, (Ir-Ru) alloys, phases of a variable (Os-Ir-Ru) composition, and newly formed laurite III, IrAsS, RhNiAs and RuAs (Figures $9 f$ and 10a-d). Remobilized secondary PGMs form polyphase aggregates in the serpentine-chlorite matrix (Figure 10c) in association with 
Ni sulfides, sulfarsenides, and arsenides. The joint occurrence of PGMs with Ni sulfides and the presence of such elements as $\mathrm{Ni}, \mathrm{Fe}, \mathrm{Te}, \mathrm{Cu}, \mathrm{Co}, \mathrm{As}$, and $\mathrm{Sb}$ in the platinum phases indicate PGE mobility in a fluid-saturated medium. The processes of the redistribution and concentration of $\mathrm{PGE}$, including refractory $\mathrm{Os}, \mathrm{Ir}$, and $\mathrm{Ru}$, occur at relatively low temperatures, reducing conditions corresponding to the formation of nickel sulfides, sulfarsenides, and arsenides, and low-temperature PGE-bearing intermetallides [110]. At the initial stage, the penetration of fluid through the permeable zones into laurite-erlichmanite led to the desulfurization of sulfides, a deviation from stoichiometry, the appearance of microdefects in the crystal lattice, and the formation of nanopores on the grain surface. These processes led to the formation of microporous structures and the separation of native Os and $\mathrm{Ru}$ (Figure 9e,f) $[108,109,111,112]$. According to the experimental data, congruent $\mathrm{RuS}_{2} \rightarrow$ native $\mathrm{Ru}$ decomposition occurs at $T=300{ }^{\circ} \mathrm{C}, \log f \mathrm{~S}_{2}=(-20)$, and $\mathrm{P}=0.5 \mathrm{kbar}$ [113-118]. The (Os-Ir-Ru) phases of a variable composition are probably the products of changes in $(\mathrm{Os}, \mathrm{Ir}, \mathrm{Ru}) \mathrm{AsS}$, since Ir has a maximum affinity with As, and irarsite therefore survives for the longest. At the same stage, secondary (newly formed) laurite III can be formed. They grow over primary laurite-erlichmanite or are confined to chloritization zones, and as a rule, they are in association with nickel and copper sulfides and sulfarsenides (Figure 10a). Irarsites IrAsS can be formed during serpentinization. In this case, irarsites are in close association with $\mathrm{Ni}_{3} \mathrm{~S}_{2}$, forming joint aggregates. The microstructural features of such aggregates indicate their simultaneous formation (Figure 10c). The physical-chemical modeling of the forms of PGE transport in the fluid systems indicates the formation of carbonyl, chloride, hydrosulfide, and bisulfide complexes, in the form of which they are transported, and the formation of secondary PGM occurs. When PGEs are transported by bisulfide complexes, and As and Sb appear in the system, PGE solubility decreases, the composition of the solution changes, and the system deviates from equilibrium. Sulfur released from bisulfide complexes reacts with $\mathrm{Ni}$ to form $\mathrm{Ni}_{3} \mathrm{~S}_{2}$.

- III-Stage of Ophiolite Obduction. Regional Metamorphism.

As the ophiolite rises to the surface, the rocks undergo repeated processes of serpentinization under the influence of metamorphogenic fluids with an increased activity of $\mathrm{O}_{2}$, As, and Sb [48]. In chromitites, chrome spinels change into chrome magnetites or magnetites. There are no clear criteria for distinguishing remobilized PGMs under the crustal conditions (under the influence of metamorphogenic fluids). We believe that non-stoichiometric platinum-metal phases, containing $\mathrm{Cu}$, $\mathrm{Te}, \mathrm{As}, \mathrm{Sb}$, and $\mathrm{O}$, could be formed under the crustal conditions. These elements can be transported by aqueous solutions, with a subsequent re-deposition $[119,120]$. These events are mainly controlled by the Eh-pH conditions, and these minerals can be formed directly in the supergenic environment. Under the conditions of a changing temperature, varying Eh-pH in the Os-S-O-H system, low $f\left(\mathrm{~S}_{2}\right)$ and exposure to an oxidizing high-temperature fluid at a temperature of about $500{ }^{\circ} \mathrm{C}$ [121], Os becomes more mobile than other PGEs, which leads to the further redistribution and redeposition of osmium. At this stage, the following PGE-containing phases can be formed: (Ru,Ir, $\mathrm{Te}, \mathrm{Ni}, \mathrm{Ba}, \mathrm{S}, \mathrm{O}),(\mathrm{Os}, \mathrm{Ir}, \mathrm{Ru}, \mathrm{As}, \mathrm{S}, \mathrm{O})$, and $(\mathrm{Ir}, \mathrm{Ni}, \mathrm{Cu}, \mathrm{Ru}, \mathrm{Os}, \mathrm{Cl})$. Most often, such phases are localized in the micro voids of early PGMs (laurite, irarsite, etc.). Another process of PGM changing is the enlargement and agglomeration of PGE nanoparticles to the micro level. During progressive metamorphism (epidote-amphibolite and amphibolite facies) and/or a thermal event (introduction of granite intrusion), the changed P-T conditions affect the stability of nanoparticles. As the temperature rises to $590-650^{\circ} \mathrm{C}$, the nanoparticles in the sulfide matrix become unstable [122], which leads to their coalescence (Figure 10b) and enlargement (to micron sizes). The accessory mineralization of the crust-metamorphogenic stage is represented by the products of the changes in $\mathrm{Ni}, \mathrm{Fe}$, and $\mathrm{Cu}$ sulfides and sulfarsenides, with the appearance of oxygen-containing phases of a non-stoichiometric composition.

\section{Conclusions}

(1) High- and medium- $\mathrm{Al}^{\prime}$ chrome spinels were formed through the interaction of mantle peridotites with tholeiite melts in a spreading setting. High-Cr chrome spinels were formed 
during the interaction of mantle peridotites with boninite melts in suprasubduction environments. The predominance of PGE sulfides over high-temperature Os-Ir-Ru alloys indicates their formation from S-saturated magma, which is typical of tholeiite melts.

(2) The formation temperatures of magmatic PGM-chromite association are estimated at $1000-1200^{\circ} \mathrm{C}$. The temperatures of olivine-spinel equilibrium, reflecting the formation of chromitites and tectonic deformation processes, range from 1000 to $740{ }^{\circ} \mathrm{C}$, and the $\log$ oxygen fugacity $f\left(\mathrm{O}_{2}\right)$ is low, ranging from $(-0.76)$ to $(-4.4)$, which indicates the upper mantle conditions, as well as the effect of reduced mantle fluids.

(3) Platinum-group mineralization in the Ulan-Sar'dag chromitites reflects a long history of formation and transformation, a change in the fluid conditions from magmatic to metamorphic ones. Primary PGMs (Os-Ir-Ru alloys-I, laurite I) were formed under the condition of a high fugacity of sulfur. The physical-chemical conditions were as follows: $T<1200-1300^{\circ} \mathrm{C}$, and $\log f\left(\mathrm{~S}_{2}\right)>(-2) /(-1)$. Under the influence of reduced fluids on chromitites, the desulfurization of laurite and the formation of secondary PGMs (native Os and Ru, Os-Ir-Ru alloys-II, laurite III, IrAsS, and RhNiAs) occur in association with serpentine, chlorite, nickel sulfides and arsenides. This association can be formed at $T=300-700{ }^{\circ} \mathrm{C}, \log f\left(\mathrm{~S}_{2}\right)=(-20)$, and $\mathrm{P}=0.5 \mathrm{kbar}$.

(4) At the stage of ophiolite obduction and exposure to a metamorphogenic fluid, especially osmium, a further redistribution of PGE occurs. New phases of a non-stoichiometric composition $(\mathrm{PGE}+\mathrm{Cu}, \mathrm{Te}, \mathrm{Ba}, \mathrm{As}, \mathrm{Sb}, \mathrm{O}$, and $\mathrm{Cl})$ are formed. During progressive metamorphism, an enlargement and agglomeration of PGE nanoparticles to the microlevel occur.

Author Contributions: Conceptualization, O.N.K. and E.V.A.; methodology, D.K.B.; software, D.K.B. and E.V.A.; validation, S.M.Z. and E.V.A.; formal analysis, O.N.K.; investigation, O.N.K. and E.V.A.; resources, O.N.K. and S.M.Z.; data curation, O.N.K.; writing—original draft preparation, O.N.K. and E.V.A.; writing—review and editing, O.N.K., S.M.Z. and E.V.A.; visualization, E.V.A. and D.K.B.; supervision, S.M.Z.; project administration, O.N.K.; funding acquisition, O.N.K. All authors have read and agreed to the published version of the manuscript.

Funding: This research was funded by the Ministry of Science and Higher Education of the Russian Federation and Russian Fond Basic Research Grant No. 16-05-00737a and 19-05-00764a. Work is done on state assignment of IGM SB RAS.

Acknowledgments: The work was carried out at the Analytical Center for multi-elemental and isotope research, SB RAS. The authors are grateful of I. Ashchepkov for constructive comments and suggestions when preparing an article.

Conflicts of Interest: The authors declare no conflicts of interest.

\section{References}

1. Zhou, M.F.; Robinson, P.T. Origin and tectonic environment of podiform chromite deposits. Econ. Geol. 1997, 92, 259-262. [CrossRef]

2. Arai, S.; Matsukage, K. Petrology of a chromitite micropod from Hess Deep, equatorial Pacific: A comparison between abyssal and alpine-type podiform chromitites. Lithos 1998, 43, 1-14. [CrossRef]

3. Dönmez, C.; Keskin, S.; Günay, K.; Çolakoğlu, A.O.; Çiftçi, Y.; Uysal, İ.; Türkel, A.; Yıldırım, N. Chromite and PGE geochemistry of the Elekdağ Ophiolite (Kastamonu, Northern Turkey): Implications for deep magmatic processes in a supra-subduction zone setting. Ore Geol. Rev. 2014, 57, 216-228. [CrossRef]

4. Ahmed, A.H.; Arai, S. Platinum group minerals in podiform chromitites of the Oman ophiolite. Can. Mineral. 2003, 41, 597-616. [CrossRef]

5. Uysal, I.; Sadiklar, M.B.; Tarkian, M.; Karsli, O.; Aydin, F. Mineralogy and composition of the chromitites and their platinum-group minerals from Ortaca (Mugla-SW Turkey): Evidence for ophiolitic chromitite genesis. Mineral. Petrol. 2005, 83, 6-13. [CrossRef]

6. Thalhammer, O.A.R.; Prochaska, W.; Mühlhans, H.W. Solid inclusions in chromspinels and platinum group element concentration from the Hochgrössen and Kraubath Ultramafic Massifs (Austria). Contrib. Mineral. Petrol. 1990, 105, 66-80. [CrossRef] 
7. Melcher, F.; Grum, W.; Simon, G.; Thalhammer, T.V.; Stumpfl, E.F. Petrogenesis of the ophiolitic giant chromite deposits of Kempirsai, Kazakhstan: A study of solid and fluid inclusions in chromite. J. Petrol. 1997, 38, 1419-1458. [CrossRef]

8. Garuti, G.; Fershtater, G.; Bea, F.; Montero, P.G.; Pushkarev, E.V.; Zaccarini, F. Platinum-group element distribution in mafic-ultramafic complexes of central and southern Urals: Preliminary results. Tectonophysics 1997, 276, 181-194. [CrossRef]

9. Zhou, M.F.; Sun, M.; Keays, R.R.; Kerrich, R.W. Controls on platinum-group elemental distribution of podiform chromitites: A case study of high-Cr and high-Al chromitites from chinese orogenic belts. Geochimica et Cosmochim. Acta 1998, 62, 677-688. [CrossRef]

10. Gervilla, F.; Proenza, J.A.; Frei, R.; González-Jiménez, J.M.; Garrido, C.J.; Melgarejo, J.C.; Meibom, A.; Díaz-martínez, R.; Lavaut, W. Distribution of platinum-group elements and Os isotopes in chromite ores from Mayarí-Baracoa Ophiolilte Belt (eastern Cuba). Contrib. Mineral. Petrol. 2005, 150, 589-607. [CrossRef]

11. Uysal, I.; Tarkian, M.; Sadıklar, M.B.; Sen, C. Platinum group-element geochemistry and mineralogy of ophiolitic chromitites from the Kop Mountains, Northeastern Turkey. Can. Mineral. 2007, 45, 355-377. [CrossRef]

12. Proenza, J.A.; Zaccarini, F.; Escayola, M.; Cábana, C.; Shalamuk, A.; Garuti, G. Composition and textures of chromite and platinum-group minerals in chromitites of the western ophiolitic belt from Córdoba Pampeans Ranges, Argentine. Ore Geol. Rev. 2008, 33, 32-48. [CrossRef]

13. Zaccarini, F.; Pushkarev, E.; Garuti, G. Platinum-group element mineralogy and geochemistry of chromitite of the Kluchevskoy ophiolite complex, central Urals (Russia). Ore Geol. Rev. 2008, 33, 20-30. [CrossRef]

14. Barnes, S.J.; Naldrett, A.J.; Gorton, M.P. The origin of the fractionation of platinum-group elements in terrestrial magmas. Chem. Geol. 1985, 53, 303-323. [CrossRef]

15. Maurel, C.; Maurel, P. Étude expérimentale de la distribution de l'aluminium entre bain silicaté basique et spinelle chromifère. Implications pétrogénétiques: Teneur en chrome des spinelles. Bull. Minéralogie 1982, 105, 197-202. [CrossRef]

16. Dick, H.J.B.; Bullen, T. Chromium-spinel as a petrogenetic indicator in abyssal and alpine-type peridotites and spatially associated lavas. Contrib. Mineral. Petrol. 1984, 86, 54-76. [CrossRef]

17. Gueddari, K.; Piboule, M.; Amosee, J. Differentiation of platinum-group elements (PGE) and of gold during partial melting of peridotites in the lherzolitic massifs of the Betico-Rifean range (Ronda and Beni Bousera). Chem. Geol. 1996, 134, 181-197. [CrossRef]

18. Kamenetsky, V.; Crawford, A.J.; Meffre, S. Factors controlling chemistry of magmatic spinel: An empirical study of associated olivine, Cr-spinel and melt inclusions from primitive rocks. J. Petrol. 2001, 42, 655-671. [CrossRef]

19. Ahmed, A.H.; Arai, S. Unexpectedly high-PGE chromitite from the deeper mantle section of the northern Oman ophiolite and its tectonic implications. Contrib. Mineral. Petrol. 2002, 143, 263-278. [CrossRef]

20. Ahmed, A.H. Diversity of platinum-group minerals in podiform chromitites of the late Proterozoic ophiolite, Eastern Desert, Egypt: Genetic implications. Ore Geol. Rev. 2007, 33, 31-45. [CrossRef]

21. Rollinson, $\mathrm{H}$. The geochemistry of mantle chromitites from the northern part of the Oman ophiolite: Inferred parental melt composition. Contrib. Mineral. Petrol. 2008, 156, 273-288. [CrossRef]

22. Akmaz, R.M.; Uysal, I.; Saka, S. Compositional variations of chromite and solid inclusions in ophiolitic chromitites from the southeastern Turkey: Implications for chromitite genesis. Ore Geol. Rev. 2014, 58, 208-224. [CrossRef]

23. Ballhaus, C.; Berry, R.; Green, D. High pressure experimental calibration of the olivine-orthopyroxene-spinel oxygen geobarometer: Implication for the oxidation state of the upper mantle. Contrib. Mineral. Petrol. 1991, 107, 27-40. [CrossRef]

24. Andrews, D.R.A.; Brenan, J.M. Phase-equilibrium constraints of the magmatic origin of laurite and Os-Ir alloy. Can. Mineral. 2002, 40, 1705-1716. [CrossRef]

25. De Hoog, J.C.M.; Gall, L. Trace element geochemistry of mantle olivine and its application to geothermometry. Ofioliti 2005, 30, 182-183.

26. Korolyuk, V.N.; Pokhilenko, L.N. Electron probe determination of trace elements in olivine: Thermometry of depleted peridotites. Russ. Geol. Geophys. 2016, 57, 1750-1758. [CrossRef]

27. Kuznetsov, A.P.; Kukushkin, Y.N.; Makarov, D.F. The use of nickel matte as a collector of precious metals in the analysis of poor products. J. Anal. Chem. USSR 1974, 29, 2156-2160. (In Russian) 
28. Beklemishev, M.K.; Kuzmin, N.M.; Zolotov, Y.A. Extraction and extraction-kinetic determination of Os using aza analogs of dibenzo-18-crown-6. J. Anal. Chem. USSR 1989, 2, 356-362. (In Russian)

29. Shlenskaya, V.I.; Khvostova, V.P.; Kadyrova, G.I. Kinetic methods for the determination of osmium and ruthenium (review). J. Anal. Chem. USSR 1973, 28, 779-784. (In Russian)

30. Rao, N.V.; Ravana, P.V. Kinetic-catalytic determination of osmium. Mikrochim. Acta 1981, 76, $269-276$. [CrossRef]

31. Belichenko, V.G.; Butov, Y.P.; Boos, R.G.; Vratkovskaya, S.V.; Dobretsov, N.L.; Dolmatov, V.A.; Zhmodik, S.M.; Konnikov, E.G.; Kuzmin, M.I.; Medvedev, V.N.; et al. Geology and Metamorphism of Eastern Sayan; Nauka: Novosibirsk, Russia, 1988. (In Russian)

32. Dobretsov, N.L.; Konnikov, E.G.; Dobretsov, N.N. Precambrian ophiolitic belts of Southern Siberia (Russia) and their metallogeny. Precambr. Res. 1992, 58, 427-446. [CrossRef]

33. Zhmodik, S.; Kiseleva, O.; Belyanin, D.; Damdinov, B.; Airiyants, E.; Zhmodik, A. PGE mineralization in ophiolites of the southeast part of the Eastern Sayan (Russia). In Proceedings of the 12th International Platinum Symposium, Abstracts, Russia, 11-14 August 2014; Anikina, E.V., Ariskin, A.A., Barnes, S.-J., Barnes, S.J., Borisov, A.A., Evstigneeva, T.L., Kinnaird, J.A., Latypov, R.M., Li, C., Maier, W.D., et al., Eds.; Institute of Geology and Geochemistry UB RAS: Yekaterinburg, Russia, 2014; pp. 221-225.

34. Kuzmichev, A.B. The Tectonic History of the Tuva-MongolianMassif: Early Baikalian, late Baikalian, and Early Caledonian Stages; Probel Publishing House: Moscow, Russia, 2004; 192p. (In Russian)

35. Kuzmichev, A.B.; Larionov, A.N. Neoproterozoic island arcs of East Sayan: Duration of magmatism (from $\mathrm{U}-\mathrm{Pb}$ zircon dating of volcanic clastics). Russ. Geol. Geophys. 2013, 54, 34-43. [CrossRef]

36. Kiseleva, O.N.; Zhmodik, S.M.; Damdinov, B.B.; Agafonov, L.V.; Belyanin, D.K. Composition and evolution of PGE mineralization in chromite ores from the Il'chir ophiolite complex (Ospa-Kitoi and Khara-Nur areas, East Sayan). Russ. Geol. Geophys. 2014, 55, 259-272. [CrossRef]

37. Sklyarov, E.V.; Kovach, V.P.; Kotov, A.B.; Kuzmichev, A.B.; Lavrenchuk, A.V.; Perelyaev, V.I.; Shipansky, A.A. Boninites and ophiolites: Problems of their relations and petrogenesis of boninites. Geol. Geophys. 2016, 57, 127-140. (In Russian) [CrossRef]

38. Kiseleva, O.; Zhmodik, S. PGE mineralization and melt composition of chromitites in Proterozoic ophiolite complexes of Eastern Sayan, Southern Siberia. Geosci. Front. 2017, 8, 721-731. [CrossRef]

39. Skopintsev, V.G. Geological Structure and Mineral Resources of the Upper Rivers Gargan, Urik, Kitoy, Onot; Results of prospecting works on the site of Kitoy (East Sayan); Report of the Samartin and Kitoy parties; Buryatia Publishing House: Ulan-Ude, Russia, 1995; Book 1; 319p. (In Russian)

40. Pavlov, N.V.; Kravchenko, G.G.; Chuprynina, I.I. Chromites from the Kempirsai Pluton; Nauka: Moscow, Russia, 1968. (In Russian)

41. Cabri, L.J. The platinum group minerals. In The Geology, Geochemistry, Mineralogy and Mineral Beneficiation of Platinum Group Elements; Published for the Geological Society of CIM; Canadian Institute of Mining, Metallurgy and Petroleum: Montreal, QC, Canada, 2002; Volume 54, pp. 13-131.

42. Kelemen, P.B. Reaction between ultramafic rock and fractionating basaltic magma I. Phase relations, the origin of the calcalkaline magma series, and the formation of discordant dunite. J. Petrol. 1990, 31, 51-98. [CrossRef]

43. Arai, S.; Yurimoto, H. Podiform chromitites from the Tari-Misaka ultramafic complex, southwestern Japan, as melt-mantle interaction products. Econ. Geol. 1994, 89, 1279-1288. [CrossRef]

44. Zhou, M.-F.; Robinson, P.T. High-chromium and high-aluminum podiform chromitites, western China: Relationship to partial melting and melt/rock interaction in the upper mantle. Int. Geol. Rev. 1994, 36, 678-686. [CrossRef]

45. Zhou, M.-F.; Robinson, P.; Malpas, J.; Li, Z. Podiform chromites in the Luobusa Ophiolite (Southern Tibet): Implications for melt-rock interaction and chromite segregation in the upper mantle. J. Petrol. 1996, 37, 3-21. [CrossRef]

46. Arai, S. Control of wall-rock composition on the formation of podiform chromitites as a result of magma/peridotite interaction. Resour. Geol. 1997, 47, 177-187.

47. Ahmed, A.H.; Harbi, H.M.; Habtoor, A.M. Compositional variations and tectonic settings of podiform chromitites and associated ultramafic rocks of the Neoproterozoic ophiolite at Wadi Al Hwanet, northwestern Saudi Arabia. J. Asian Earth Sci. 2012, 56, 118-134. [CrossRef] 
48. Prichard, H.M.; Lord, R.A.; Neary, C.R. A model to explain the occurrence of platinum- and palladium- rich ophiolite complexes. J. Geol. Soc. 1996, 153, 323-328. [CrossRef]

49. Tsoupas, G.; Economou-Eliopoulos, M. High PGE contents and extremaly abundant PGE-minerals hosted in chromitites from Veria ophiolite complex, northern Greece. Ore Geol. Rev. 2008, 33, 3-19. [CrossRef]

50. O'Driscoll, B.; Day, J.M.D.; Walker, R.J.; Daly, J.S.; McDonough, W.F.; Piccoli, P.M. Chemical heterogeneity in the upper mantle recorded by peridotites and chromitites from the Shetland Ophiolite Complex. Scotland. Earth Planet. Sci. Lett. 2012, 333, 226-237. [CrossRef]

51. Gurskaya, L.I.; Smelova, L.V.; Kolbantsev, L.R.; Lyakhnitskaya, V.D.; Lyakhnitsky, Y.S.; Shakhova, S.N. Platinoids of Chromite-Bearing Massifs of the Polar Urals; Publishing House SPb Card Factory VSEGEI: St. Petersburg, Russia, 2005; 306p. (In Russian)

52. Arai, S. Characterization of spinel peridotites by olivine-Spinel compositional relationships: Review and interpretation. Chem. Geol. 1994, 113, 191-204. [CrossRef]

53. Leblanc, M.; Violette, J.F. Distribution of Aluminium-rich and Chromium-rich chromite pods in ophiolite peridotites. Econ. Geol. 1983, 78, 293-301. [CrossRef]

54. Zhou, M.F.; Bai, W.J. Chromite deposits in China and their origin. Miner. Depos. 1992, 27, 192-199. [CrossRef]

55. Leblanc, M. Chromite and ultramafic rock compositional zoning through a paleotransform fault, Poum, New Caledonia. Econ. Geol. 1995, 90, 2028-2039. [CrossRef]

56. Graham, I.T.; Franklin, B.J.; Marshall, B. Chemistry and mineralogy of podiform chromitite deposits, southern NSW, Australia: A guide to their origin and evolution. Mineral. Petrol. 1996, 37, 129-150. [CrossRef]

57. Economou-Ellopoulos, M. Platinum-group element distribution in chromite ores from ophiolite complexes: Implications for their exploration. Ore Geol. Rev. 1996, 11, 363-381. [CrossRef]

58. Proenza, J.; Gervilla, F.; Melgarejo, J.C.; Bodinier, J.L. Al-and Cr-rich chromitites from the Mayari-Baracoa Ophiolitic Belt (Eastern Cuba): Consequence of interaction between volatile-rich melts and peridotite in suprasubduction mantle. Econ. Geol. 1999, 94, 547-566. [CrossRef]

59. Ahmed, A.H.; Arai, S.; Attia, A.K. Petrological characteristics of podiform chromitites and associated peridotites of the Pan African Proterozoic ophiolite complexes of Egypt. Miner. Depos. 2001, 36, $72-84$. [CrossRef]

60. Thayer, P.T. Principal features and origin of podiform chromite deposits, and some observations on the Guleman-Soridag district, Turkey. Econ. Geol. 1964, 59, 1497-1524. [CrossRef]

61. Thayer, T.P. Chromite Segregations as Petrogenetic Indicators; 1 (Special Publications); The Geological Society of South Africa: Johannesburg, South Africa, 1970; pp. 380-389.

62. Uysal, I.; Tarkian, M.; Sadiklar, M.B.; Zaccarini, F.; Meisel, T.; Garuti, G.; Heidrich, S. Petrology of Al- and Cr-rich ophiolitic chromitites from the Muğla, SW Turkey: Implications from composition of chromite, solid inclusions of platinum-group mineral, silicate, and base-metal mineral, and Os-isotope geochemistry. Contrib. Mineral. Petrol. 2009, 158, 659-674. [CrossRef]

63. Xiong, F.; Yang, J.; Liu, Z.; Guo, G.; Chen, S.; Xu, X.; Li, Y.; Liu, F. High-Cr and high-Al chromitite found in western Yarlung-Zangbo suture zone in Tibet. Acta Petrol. Sin. 2013, 29, 1878-1908.

64. González-Jiménez, J.M.; Proenza, J.A.; Gervilla, F.; Melgarejo, J.C.; Blanco-Moreno, J.A.; Ruiz-Sánchez, R.; Griffin, W.L. High-Cr and high-Al chromitites from the Sagua de Tánamo district, Mayarí-Cristal ophiolitic massif (eastern Cuba): Constraints on their origin from mineralogy and geochemistry of chromian spinel and platinum-group elements. Lithos 2011, 125, 101-121. [CrossRef]

65. Kelemen, P.B.; Shimizu, N.; Salters, V.J.M. Extraction of mid-ocean-ridge basalt from the upwelling mantle by focused flow of melt in dunite channels. Nature 1995, 375, 747-753. [CrossRef]

66. Arai, S. Role of dunite in genesis of primitive MORB. Proc. Jpn. Acad. 2005, B 81, 14-19. [CrossRef]

67. Arai, S.; Miura, M. Podiform chromitites do form beneath mid-ocean ridges. Lithos 2015, 232, $143-149$. [CrossRef]

68. Kiseleva, O.N.; Airiyants, E.V.; Belyanin, D.K.; Zhmodik, S.M. Geochemical Features of Peridotites and Volcanogenic-Sedimentary Rocks of the Ultrabasic-Basitic Massif of Ulan-Sar'dag (East Sayan, Russia); The Bulletin of Irkutsk State University: Irkutsk, Russia, 2019. (In Russian)

69. Wilson, M. Igneous Petrogenesis; Unwin Hyman: London, UK, 1989.

70. Jonson Kevin, T.M.; Dick Henry, J.B. Open System Melting and Temporal and Spatial Variation of Peridotite and Basalt at the Atlantis II Fracture Zone. J. Geophys. Res. 1992, 97, 9219-9241. [CrossRef] 
71. Garuti, G.; Pushkarev, E.V.; Thalhammer, O.A.R.; Zaccarini, F. Chromitites of the Urals (Part 1): Overview of chromite mineral chemistry and geotectonic setting. Ofioliti 2012, 37, 27-53.

72. Jenner, G.A. Geochemistry of high-Mg andesites from Cape Vogel, Papua New Guinea. Chem. Geol. 1981, 33, 307-332. [CrossRef]

73. Kamenetsky, V.S.; Sobolev, A.V.; Eggins, S.M.; Crawford, A.J.; Arculus, R.J. Olivine enriched melt inclusions in chromites from low-Ca boninites, Cape Vogel, Papua New Guinea: Evidence for ultramafic primary magma, refractory mantle source and enriched components. Chem. Geol. 2002, 83, 287-303. [CrossRef]

74. Walker, D.A.; Cameron, W.E. Boninite primary magmas: Evidence from the Cape Vogel Peninsula, PNG. Contrib. Mineral. Petrol. 1983, 83, 150-158. [CrossRef]

75. Cameron, W.E. Petrology and origin of primitive lavas from the Troodos ophiolite, Cyprus. Contrib. Mineral. Petrol. 1985, 89, 239-255. [CrossRef]

76. Flower, M.F.J.; Levine, H.M. Petrogenesis of a tholeiite-boninite sequence from Ayios Mamas, Troodos ophiolite: Evidence for splitting of a volcanic arc? Contrib. Mineral. Petrol. 1987, 97, 509-524. [CrossRef]

77. Page, P.; Barnes, S.J. Using trace elements in chromites to constrain the origin of podiform chromitites in the Thetford Mines Ophiolite, Québec, Canada. Econ. Geol. 2009, 104, 997-1018. [CrossRef]

78. Shibata, T.; Thompson, G.; Frey, F.A. Tholeiitic and alkali basalts from the mid Atlantic ridge at $43^{\circ}$ N. Contrib. Mineral. Petrol. 1979, 70, 127-141. [CrossRef]

79. Le Roex, A.P.; Dick, H.J.B.; Gulen, L.; Reid, A.M.; Erlank, A.J. Local and regional heterogeneity in MORB from the mid-Atlantic ridge between $54.5^{\circ} \mathrm{S}$ and $51^{\circ} \mathrm{S}$ : Evidence for geochemical enrichment. Geochim. Cosmochim. Acta 1987, 51, 541-555. [CrossRef]

80. Presnall, D.C.; Hoover, J.D. High pressure phase equilibrium constraints on the origin of mid-ocean ridge basalts. Geochem. Soc. Spec. Pap. 1987, 1, 75-89.

81. Rollinson, H. Chromite in the mantle section of the Oman ophiolite: A new genetic model. Isl. Arc 2005, 14, 542-550. [CrossRef]

82. Barnes, S.J.; Kunilov, V.Y. Spinels and Mg ilmenites from the Noril'sk and Talnakh intrusions and other mafic rocks of the Siberian flood basalt province. Econ. Geol. 2000, 95, 1701-1717. [CrossRef]

83. Burns, L.E. The Borger Range ultramafic and mafic complex, south-central Alaska: Cumulative fractionates of island-arc volcanics. Can. J. Earth Sci. 1985, 22, 1020-1038. [CrossRef]

84. Volchenko, Y.A.; Ivanov, K.S.; Koroteev, V.A.; Auge, T. Structural-substantial evolution of the Urals platiniferous belt's complexes in the time of Uralian type chromite-platinum deposits formation. Part I. Lithosphere 2007, 3, 3-27.

85. Irvine, T.N. Chromian spinel as a petrogenetic indicator: Part II. Petrologic applications. Can. J. Earth Sci. 1967, 4, 71-103. [CrossRef]

86. Henry, D.; Medaris, L. Application of pyroxene and olivine-spinel geothermometers to spinel peridotites in South-western Oregon. Am. J. Sci. 1980, 280, 211-231.

87. Bedard, J.H. A new projection scheme and differentiation index for Cr-spinels. Lithos 1997, 42, 37-45. [CrossRef]

88. Ashchepkov, I.V. Program of the mantle thermometers and barometers: Usage for reconstructions and calibration of PT methods. Vestn. Otd. Nauk Zemle 2011, 3, NZ6008. [CrossRef]

89. Ashchepkov, I.V.; Pokhilenko, N.P.; Vladykin, N.V.; Rotman, A.Y.; Afanasiev, V.P.; Logvinova, A.M.; Kostrovitsky, S.I.; Pokhilenko, L.N.; Karpenko, M.A.; Kuligin, S.S.; et al. Reconstruction of mantle sections beneath Yakutian kimberlite pipes using monomineral thermobarometry. Geol. Soc. Spec. Publ. 2008, 293, 335-352. [CrossRef]

90. O'Neill, H.S.C.; Wal, V.J. The olivine orthopyroxene-spinel oxygen geobarometer, the nickel precipitation curve, and the oxygen fugacity of the Earth's upper mantle. J. Petrol. 1987, 28, 1169-1191. [CrossRef]

91. Taylor, W.R.; Kammerman, M.; Hamilton, R. New thermometer and oxygen fugacity sensor calibrations for ilmenite and chromium spinel-bearing peridotitic assemblages. In Proceedings of the 7th International Kimberlite Conference, Cape Town, South Africa, 11-17 April 1998; Extended Abstracts. pp. 891-901.

92. Lorand, J.P.; Keays, R.R.; Bodiner, J.R. Copper- and noble metal enrichment across the asthenosphere-lithosphere mantle diapiris: The Lanzo lherzolite massif. J. Petrol. 1993, 34, 1111-1140. [CrossRef] 
93. Brugmann, G.E.; Armdt, N.T.; Hoffmann, A.W.; Tobschall, H.J. Nobel metal abundances in Komatiite suites from Alexo, Ontario and Gorgona Island, Colombia. Geochim. Cosmochim. Acta 1987, 51, 2159-2169. [CrossRef]

94. Wang, K.-L.; Chu, Z.; Gornova, M.A.; Dril, S.; Belyaev, V.A.; Lin, K.-Y.; O’Reilly, S.Y. Depleted SSZ type mantle peridotites in Proterozoic Eastern Sayan ophiolotes in Siberia. Geodyn. Tectonophys. 2017, 8, 583-587. [CrossRef]

95. Agafonov, L.V.; Lkhamsuren, J.; Kuzhuget, K.S.; Oidup, C.K.B. Platinum-Group Element Mineralization of Ultramafic-Mafic Rocks in Mongolia and Tuva; Tomurtogoo, O., Ed.; Ulaanbaatar Publishing House: Ulaanbaatar, Mongolia, 2005. (In Russian)

96. Page, N.J.; Engin, T.; Singer, D.A.; Haffty, J. Distribution of platinum-group elements in the Bati Kef chromite deposit, Güleman-Elaziğ area, Eastern Turkey. Econ. Geol. 1984, 79, 177-184. [CrossRef]

97. Yaman, S.; Ohnenstetter, M. Distribution of platinum-group elements of chromite deposits within ultramafic zone of Mersin ophiolite (south Turkey). Bull. Geol. Congr. Turk. 1991, 6, 253-261.

98. Garuti, G.; Pushkarev, E.V.; Zaccarini, F. Diversity of chromite-PGE mineralization in ultramafic complexes of the Urals. In Proceedings of the Platinum-Group Elements-From Genesis to Beneficiation and Environmental Impact: 10th International Platinum Symposium, Oulu, Finland, 8-11 August 2005; Geological Survey of Finland: Esbo, Finland, 2005.

99. Ballhaus, C.; Sylvester, P. PGE enrichment processes in the Merensky reef. J. Petrol. 2000, 41, 454-561. [CrossRef]

100. Matveev, S.; Ballhaus, C. Role of water in the origin of podiform chromititedeposits. Earth Planet. Sci. Lett. 2002, 203, 235-243. [CrossRef]

101. Sattari, P.; Brenan, J.M.; Horn, I.; McDonough, W.F. Experimental constraints in the sulfide-and chromite-silicate melt partitioning behaviour of rhenium and platinum-group elements. Ecol. Geol. 2002, 97, 385-398. [CrossRef]

102. Fleet, M.E.; Crocket, J.H.; Lin, M.H.; Stone, W.E. Laboratory partitioning of platinum-group elements and gold with application to magmatic sulfide-PGE deposits. Lithos 1999, 47, 127-142. [CrossRef]

103. Kiseleva, O.N.; Airiyants, E.V.; Belyanin, D.K.; Zhmodik, S.M. Geochemical and mineralogical indicators (Cr-spinelides, Platinum Group Minerals) of the geodynamic settings of formation of maficultramafic Ulan Saridag massif (Eastern Sayan). In Proceedings of the EGU General Assembly Conference Abstracts, Vienna, Austria, 8-13 April 2018.

104. Prichard, H.M.; Tarkian, M. Platinum and palladium minerals from two PGElocalities in the Shetland ophiolite complex. Can. Mineral. 1988, 26, 979-990.

105. Garuti, G.; Zaccarini, F.; Economou-Eliopoulos, M. Paragenesis and composition of laurite from chromitites of Othrys (Greece): Implications for Os-Ru fractionation in ophiolitic upper mantle of the Balkan peninsula. Miner. Depos. 1999, 34, 312-319. [CrossRef]

106. Brenan, J.M.; Andrews, D. High-temperature stability of laurite and Ru-Os-Ir alloy and their role in PGE fractionation in mafic magmas. Can. Mineral. 2001, 39, 341-360. [CrossRef]

107. Ballhaus, C.; Bockrath, C.; Wohlgemuth-Ueberwasser, C.; Laurenz, V.; Berndt, J. Fractionation of the noble metals by physical processes. Contrib. Mineral. Petrol. 2006, 152, 667-684. [CrossRef]

108. Bockrath, C.; Ballhaus, C.; Holzheid, A. Stabilities of laurite $\mathrm{RuS}_{2}$ and monosulphide liquid solution atmagmatic temperature. Chem. Geol. 2004, 208, 265-271. [CrossRef]

109. Finnigan, C.S.; Brenan, J.M.; Mungall, J.E.; McDonough, W.F. Experiments and models bearing on the role of chromite as a collector of platinum group minerals by local reduction. J. Petrol. 2008, 49, 1647-1665. [CrossRef]

110. Dick, H.J.B. Terrestrial nickel-iron from the josephinite peridotite, its geologic occurrence, associations and origin. Earth Planet. Sci. Lett. 1974, 24, 291-298. [CrossRef]

111. Zaccarini, F.; Proenza, J.A.; Ortega-Gutiérrez, F.; Garuti, G. Platinum group minerals in ophioliticchromitites from Tehuitzingo (Acatlán complex, southern Mexico): Implications for postmagmatic modification. Miner. Petrol. 2005, 84, 147-168. [CrossRef]

112. Garuti, G.; Proenza, J.A.; Zaccarini, F. Distribution and mineralogy of platinum-group elements in altered chromitites of the Campo Formoso layered intrusiyn (Bahia State, Brazil): Control by magmatic and hydrothermal processes. Miner. Petrol. 2007, 89, 159-188. [CrossRef] 
113. Stockman, H.W.; Hlava, P.F. Platinum-group minerals in Alpine chromitites from southwestern Oregon. Econ Geol. 1984, 79, 492-508. [CrossRef]

114. Nilsson, L.P. Platinum-group mineral inclusions in chromitite from Osthammeren ultramafic tectonite body, south central Norway. Mineral. Petrol. 1990, 42, 249-263. [CrossRef]

115. Bowles, J.F.W.; Gize, A.P.; Vaughan, D.J.; Norris, S.J. Development of platinum-group minerals in laterites-Initial comparison of organic and inorganic controls. Trans. Inst. Min. Metall. (Sect. B Appl. Earth Sci.) 1994, 103, 53-56.

116. Garuti, G.; Zaccarini, F. In situ alteration of platinum-group minerals at low temperature: Evidence from serpentinized and weathered chromitite of the Vourinos complex, Greece. Can. Mineral. 1997, 35, 611-626.

117. Bai, W.; Robinson, P.T.; Fang, Q.; Yang, J.; Yan, B.; Zhang, Z.; Hu, X.-F.; Zhou, M.-F.; Malpas, J. The PGE and base-metal alloys in the podiform chromitites of the Luobusa ophiolite, southern Tibet. Can. Mineral. 2000, 38, 585-598. [CrossRef]

118. Evans, B.V.; Hattori, K.; Barronet, A. Serpentinite: What, Why, Where? Elements 2013, 9, 99-106. [CrossRef]

119. Bowles, J.F.W. The development of platinum-group minerals in laterites. Econ. Geol. 1986, 81, 1278-1285. [CrossRef]

120. Bowles, J.F.W.; Lyon, J.C.; Saxton, J.M.; Vaughan, D.J. The origin of Platinum Group Minerals from the Freetown intrusions, Sierra Leone, inferred from osmium isotope systematics. Econ. Geol. 2000, 95, 539-548. [CrossRef]

121. Xiong, Y.; Wood, A. Experimental quantifycation of hydrothermal solubility of platinum- group elements with special reference to porphyry copper environments. Mineral. Petrol. 2000, 68, 1-28. [CrossRef]

122. González-Jiménez, J.M.; Reich, M.; Camprubí, T.; Gervilla, F.; Griffin, W.L.; Colás, V.; O’Reilly, S.Y.; Proenza, J.A.; Pearson, N.J.; Centeno-García, E. Thermal metamorphism of mantle chromites and the stability of noble-metal nanoparticles. Contrib. Mineral. Petrol. 2015, 170, 15. [CrossRef]

(C) 2020 by the authors. Licensee MDPI, Basel, Switzerland. This article is an open access article distributed under the terms and conditions of the Creative Commons Attribution (CC BY) license (http://creativecommons.org/licenses/by/4.0/). 